\title{
Diversity and Toxicity of the Genus Coolia Meunier in Brazil, and Detection of 44-methyl Gambierone in Coolia tropicalis
}

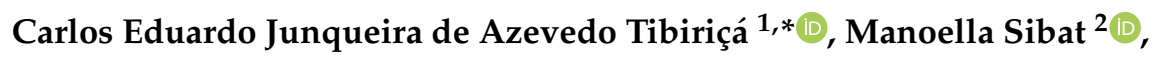 \\ Luciano Felício Fernandes ${ }^{3}$, Gwenaël Bilien ${ }^{4}\left(\mathbb{D}\right.$, Nicolas Chomérat ${ }^{4}$, Philipp Hess ${ }^{4, *}$ \\ and Luiz L. Mafra Jr ${ }^{1, *}$ \\ 1 Universidade Federal do Paraná, Centro de Estudos do Mar, Cx, Postal 61, \\ Pontal do Paraná PR 83255-976, Brazil \\ 2 IFREMER, DYNECO, Phycotoxins Laboratory, 44000 Nantes, France; manoella.sibat@ifremer.fr \\ 3 Universidade Federal do Paraná, Departamento de Botânica, Cx. Postal 19031, Curitiba PR 81531-990, Brazil; \\ lff@ufpr.br \\ 4 Ifremer, LITTORAL, Laboratory of Environment and Resources Western Britanny, 29900 Concarneau, France; \\ gwenael.bilien@ifremer.fr (G.B.); nicolas.chomerat@ifremer.fr (N.C.) \\ * Correspondence: azevedo.junqueira@gmail.com (C.E.J.d.A.T.); philipp.hess@ifremer.fr (P.H.); \\ luiz.mafra@ufpr.br (L.L.M.J.)
}

Received: 14 April 2020; Accepted: 13 May 2020; Published: 15 May 2020

\begin{abstract}
Coolia is a genus of marine benthic dinoflagellates which is widely distributed in tropical and temperate zones. Toxicity has been reported in selected Coolia species, although the identity of causative compounds is still controversial. In this study, we investigated the taxonomical and toxicological aspects of Coolia species from Brazil. Since light- and electron microscopy-based morphology was not enough to distinguish small-celled species, ITS and LSU D1-D3 phylogenetic analyses were used for species definition. Cultures of Coolia palmyrensis and Coolia santacroce were established from samples collected along the northeastern Brazilian coast, the first record of both species in South Atlantic waters. Cultures of Coolia malayensis and Coolia tropicalis were also established and exhibited acute in vivo toxicity to adults of Artemia salina, while C. palmyrensis and C. santacroce were non-toxic. The presence of 30 yessotoxin analogues, 7 metabolites of Coolia and 44 Gambierdiscus metabolites was screened in 14 strains of Coolia. 44-methyl gambierone (formerly referred to as MTX3) and a new isomer of this compound were detected only in C. tropicalis, using both low- and high-resolution LC-MS/MS. To our knowledge, this is the first report of gambierone analogues in dinoflagellates other than Gambierdiscus; the role of $C$. tropicalis in ciguatera poisoning thus deserves to be considered in further investigations.
\end{abstract}

Keywords: benthic microalgae; toxic dinoflagellates; toxicity assay; cooliatoxin; 44-methyl gambierone

Key Contribution: Coolia santacroce and Coolia palmyrensis were described for the first time in the South Atlantic Ocean. Coolia malayensis and Coolia tropicalis were acutely toxic to Artemia salina via in vivo assays, but no yessotoxin analogues were found. Instead, the presence of 44-methyl gambierone and of a new isomer was first reported in C. tropicalis.

\section{Introduction}

The marine benthic dinoflagellates are recognized for producing a multitude of toxic compounds [1]. Studies concerning these microalgae have increased since the 1970s, after their identification as causative agents of ciguatera poisoning $(\mathrm{CP})$, the most common non-bacterial intoxication affecting human 
consumers of seafood in the world [2]. Today, ciguatoxins (CTXs) and, to a lesser degree, maitotoxins (MTXs) are regarded as the responsible compounds for CP symptoms [3-5]. These toxins, as well as gambieric acids [6], gambierol [7], gambieroxide [8], and gambierones [9], are produced by the dinoflagellate genus Gambierdiscus. However, other benthic dinoflagellates may also pose a threat marine organisms and human health, through the production of toxins such as palytoxin and analogues by Ostreopsis spp. [2], okadaic acid and dinophysistoxins by Prorocentrum spp. [10], and amphidinols by Amphidinium spp. [11,12]. Toxicity has also been reported for the broadly distributed genus Coolia [13], although the identity of causative compounds is still unresolved in this case.

Coolia is present in both tropical and temperate seas [14], and to date, eight species have been described, namely C. monotis, C. tropicalis, C. areolata, C. canariensis, C. malayensis, C. palmyrensis, C. santacroce and C. guanchica [15]. Before 1995, Coolia monotis was the only species of the genus, when $C$. tropicalis was described on a morphological basis [16] and later re-described with molecular support [17]. Molecular techniques are also useful for distinguishing morphologically closely related species such as C. monotis, C. malayensis, C. palmyrensis and C. santacroce [18,19], which could be otherwise misidentified $[1,20]$. In contrast, no molecular data are available for $C$. areolata yet, but this species can be easily identified using morphological features [1]. Therefore, integrative taxonomy should preferably be used for correct identification of Coolia spp., and future studies should focus on clarifying morphological differences among closely related species.

The most widely distributed species within the genus is C. malayensis, found in every ocean on both tropical and temperate zones [14,21,22]. Other species like C. tropicalis, C. canariensis and C. palmyrensis are present in both Atlantic and Pacific oceans, but they are likely restricted to tropical areas [19,22-24]. The reported geographical distribution of the remaining species is much more limited. For instance, C. monotis has only been reported in the Atlantic Ocean [14,24], C. santacroce in the U.S. Virgin Islands [19] and C. guanchica in the Canary Islands [15]. C. areolata was cited only from the Indian Ocean [25]. In Brazil, thus far, C. malayensis can be found along the entire coast, while C. tropicalis and C. canariensis are restricted to warmer, northern waters [12,26-28].

In an earlier study, Coolia sp. (reported as C. monotis) exhibited positive effects on hemolytic assays [29] and, since then, this dinoflagellate genu has been considered potentially toxic to marine organisms [1]. Later studies confirmed the toxicity in strains of C. tropicalis, C. malayensis, C. palmyrensis and C. santacroce $[19,27,30-32]$, although no toxic effects have been reported in C. monotis, C. canariensis, C. guanchica, and in other strains of C. malayensis $[15,19,33,34]$. Furthermore, toxic compounds, named cooliatoxins, have been described from C. tropicalis [30] and C. malayensis [32], but their chemical identities remain unclear [13]. In view of the marked species-specific differences in toxicity and the inconsistent findings described above, any local assessment of environmental risks associated to the presence of Coolia must be preceded by a proper characterization of the genus diversity, as well as a comprehensive screening for individual, toxic compounds and toxic effects among different species.

In the present study, we investigated the phylogeny, morphology, toxin production and toxicity of Coolia species from different coastal areas in Brazil, including samples from poorly explored sites. Molecular analysis and electron microscopy were carried out for species identification. As a result, the distribution range of $C$. malayensis, C. palmyrensis, C. santacroce and C. tropicalis was expanded, and toxic and non-toxic strains were characterized and differentiated. We evaluated the toxicity of these four species through acute exposure assays with adults of the microcrustacean Artemia salina. Moreover, 14 different monoclonal cultures were screened using either low and high mass spectrometry for the presence of several toxic compounds, including cooliatoxins, yessotoxins, ciguatoxins, maitotoxins, gambieric acids, gambierones, gambierol and gambieroxide. 


\section{Results}

\subsection{Phylogenetics}

Species identification was initially evaluated by phylogenetic analyses based on ITS region (ITS 1, 5.8S rDNA and ITS 2) and partial LSU rDNA (D1-D3 domains). The ITS phylogenetic analyses comprised 53 sequences, including 11 sequences from our monoclonal cultures, three outgroup sequences, and sequences retrieved from GenBank. The final ITS alignment was 336-base pairs long. The best-fit model was a $\operatorname{TrN}$ (Tamura-Nei model), with base frequencies of $\mathrm{A}=0.27370, \mathrm{C}=0.14067$, $\mathrm{G}=0.22437, \mathrm{~T}=0.36125$, assuming a gamma distribution shape $(\mathrm{G}=0.850)$. For LSU D1-D3, the final alignment comprised 65 sequences with 745 base pairs. The best-fit model was also a $\operatorname{TrN}$, with base frequencies of $\mathrm{A}=0.29774, \mathrm{C}=0.15203, \mathrm{G}=0.23614, \mathrm{~T}=0.31410$, assuming gamma distribution shape $(G=0.708)$.

Phylogenetic analyses were performed with two reconstruction methods: maximum likelihood (ML) and Bayesian inference (BI). Considering that both ML and BI analyses gave the same tree topology and relationships among clades, only the majority-rule consensus tree of the ML analysis is shown herein. Six distinct clades were found in the phylogeny inferred from ITS sequences (C. malayensis, C. monotis, C. santacroce, C. palmyrensis, C. canariensis and C. tropicalis), and seven clades from LSU D1-D3 (same clades as those inferred from ITS plus Coolia guanchica) (Figures 1 and 2). The sequences from Brazil fit within four (C. malayensis, C. santacroce, C. palmyrensis and C. tropicalis) out of the seven described species containing molecular data. 


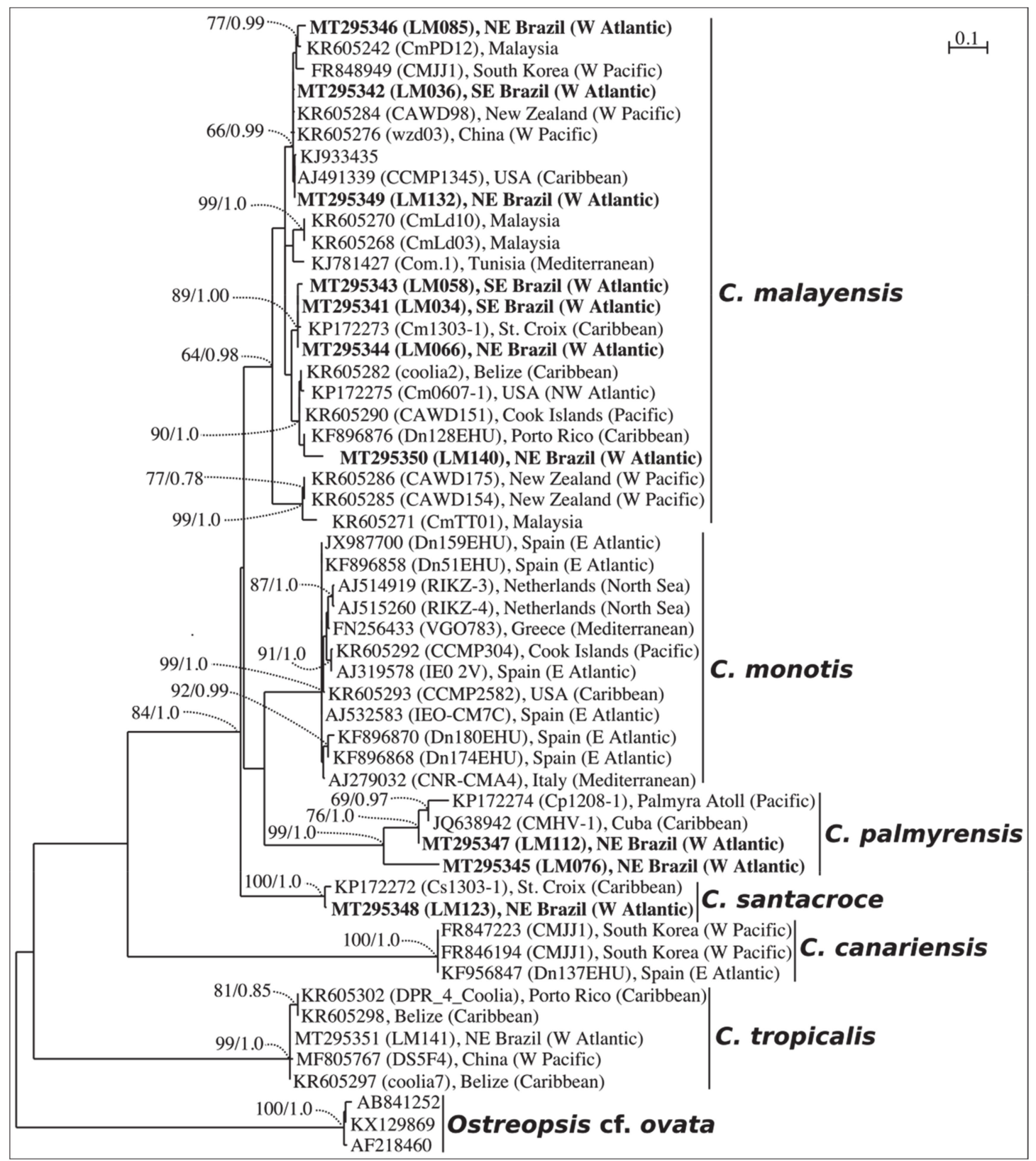

Figure 1. Maximum Likelihood phylogenetic tree inferred from ITS 1, 5.8S rDNA and ITS 2 sequences of various Coolia strains (LM034-LM141). Ostreopsis cf. ovata is used as outgroup. Black vertical bars show distinct Coolia clades. Numbers at nodes indicate bootstrap support values from Maximum Likelihood (ML) and posterior probabilities from Bayesian Inference (BI). 


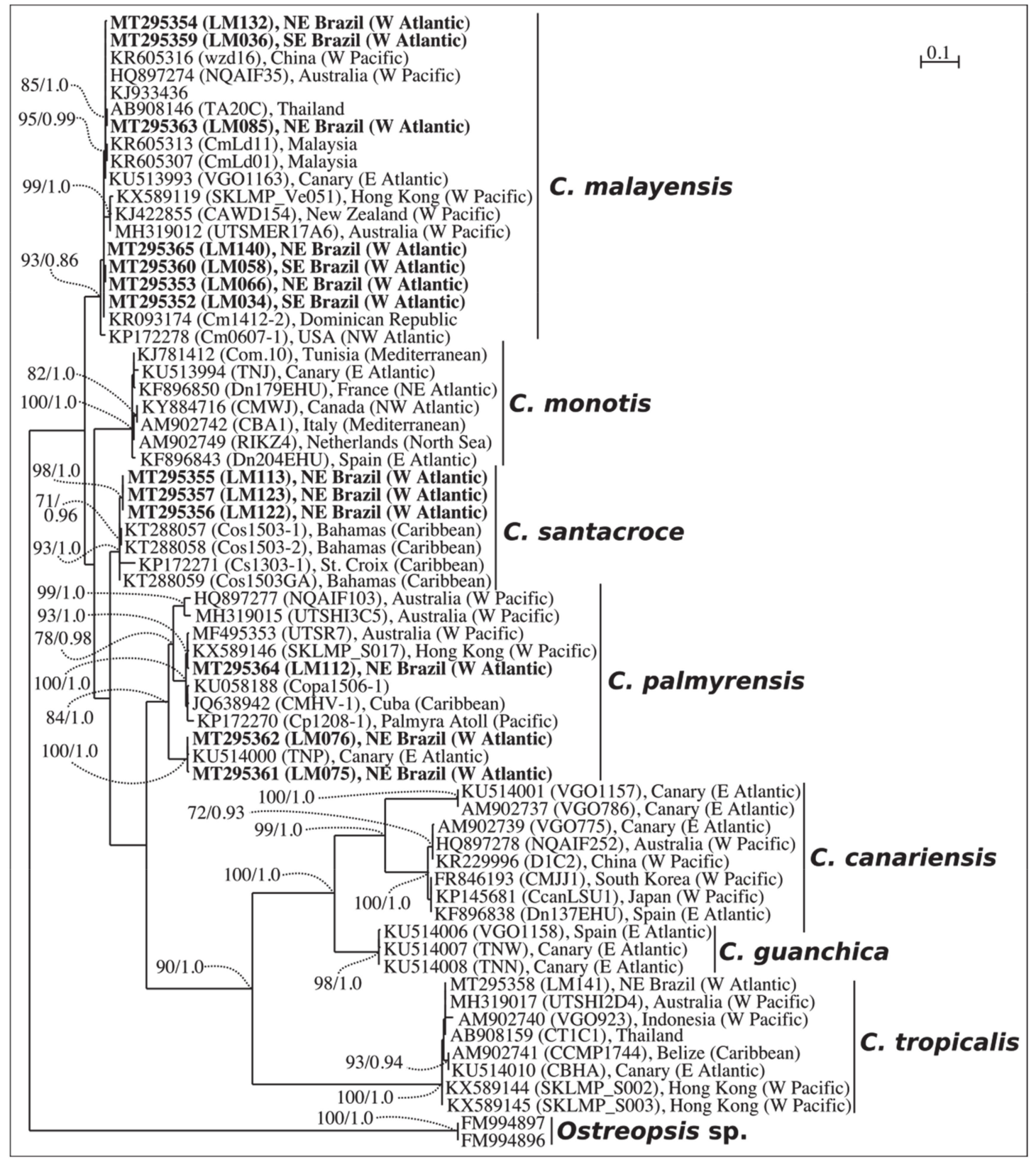

Figure 2. Maximum Likelihood phylogenetic tree inferred from LSU D1-D3 sequences of various Coolia strains (LM034-LM141). Ostreopsis sp. is used as outgroup. Black vertical bars show distinct Coolia clades. Numbers at nodes indicate bootstrap support values from Maximum Likelihood (ML) and posterior probabilities from Bayesian Inference (BI).

\subsection{Morphology and Geographical Distribution}

Cells of all Coolia species evaluated in the present study were nearly spherical, with slightly different degrees of anteroposterior compression among species. Living cells contained many golden-brown chloroplasts. The thecal plate formulae followed a Po, 3', 7", 5"', $2^{\prime \prime \prime \prime}$ pattern (according to [1]).

Cells of C. malayensis were 23.3 to $29.8-\mu \mathrm{m}$ deep (dorso-ventral length, DV) (mean \pm standard deviation $(\mathrm{SD})=26.7 \mu \mathrm{m} \pm 1.9, \mathrm{n}=26), 19.6$ to $29.3 \mu \mathrm{m}$ wide $(\mathrm{W})(24.3 \pm 3.0, \mathrm{n}=13)$ and 16.6 to $25.3 \mu \mathrm{m}$ long $(22.0 \pm 2.6, \mathrm{n}=15)$ (antero-posterior length, AP). The DV/W ratio was 0.98-1.37 (1.12 \pm 0.15 , $\mathrm{n}=11$ ). The apical pore plate Po was short, $6.3 \pm 0.5 \mu \mathrm{m}$, and slightly curved, contiguous to plates $1^{\prime}, 2^{\prime}$, with plate $3^{\prime}$ dorsally and left displaced, measuring $6.3 \pm 0.5 \mu \mathrm{m}$ (Table 1). The first apical plate $\left(1^{\prime}\right)$ was oblong and hexagonal, with pore density equal to 0.30 pores $\mu \mathrm{m}^{-1}$ (Figure 3 ; Table 1 ). 
The largest plate in apical view was the sixth pre-cingular plate $\left(6^{\prime \prime}\right)$, touching plates $1^{\prime}, 3^{\prime}, 5^{\prime \prime}$, and $7^{\prime \prime}$, with pore density of 0.24 pores $\mu \mathrm{m}^{-1}$ (Figure 3; Table 1 ). The seventh pre-cingular plate (7") was small and quadrangular, with 4-9 pores (Table 1). The large third post-cingular plate ( $\left.3^{\prime \prime \prime}\right)$ could be fully viewed in antapical view, exhibiting pore density of 0.18 pores $\mu \mathrm{m}^{-1}$ (Figure 3 ; Table 1 ) and occupying most of the hypotheca (Figure 3). The second antapical plate (2"') was small and triangular, containing 3-8 pores (Table 1). The thecal surface was smooth and the mean diameter of thecal pores, $0.33 \pm 0.04 \mu \mathrm{m}(\mathrm{n}=36)$. Strains of $C$. malayensis were obtained from material collected in the following Brazilian States: São Paulo, Rio de Janeiro, Bahia, Alagoas and Rio Grande do Norte (Table 1, Figure 4).

Cells of C. santacroce measured 24.0-30.7 $\mu \mathrm{m}$ in DV $(27.6 \pm 1.7, \mathrm{n}=30), 23.2-29.7 \mu \mathrm{m}$ in W $(26.5 \pm 1.8$, $\mathrm{n}=26)$ and $18.0-30.0 \mu \mathrm{m}$ in $\operatorname{AP}(23.8 \pm 3.1, \mathrm{n}=16)$. The DV/W ratio was $0.98-1.21(1.05 \pm 0.06, \mathrm{n}=20)$. The mean diameter of thecal pores was $0.32 \mu \mathrm{m}(\mathrm{SD}=0.04, \mathrm{n}=40)$ and the apical pore plate was $5.9 \pm 0.8 \mu \mathrm{m}$ long (Table 1 ). The mean pore density was 0.29 pores $\mu \mathrm{m}^{-1}$ for plate $1^{\prime}, 0.25$ pores $_{\mu \mathrm{m}^{-1}}$ for plate $6^{\prime \prime}$, and 0.22 pores $\mu \mathrm{m}^{-1}$ for plate $3^{\prime \prime \prime}$ (Table 1 ). Cells of $C$. santacroce had $4-10$ pores in plate 7", and 4-9 pores in plate 2"'" (Table 1). Like in C. malayensis, size of the plate 3"' was impossible to measure in C. santacroce, due to the cell curvature (Figures 3 and 5). Specimens originating the C. santacroce strains used in the present study were sampled in Abrolhos Archipelago, Bahia (Table 1, Figure 4).

Mean cell size of C. palmyrensis was 19.1-28.4 $\mu \mathrm{m}$ DV $(24.1 \pm 2.3, \mathrm{n}=27), 17.4-27.3 \mu \mathrm{m} \mathrm{W}(22.2 \pm 2.4$, $\mathrm{n}=8)$ and 16.9-26.1 $\mu \mathrm{m}$ AP $(21.0 \pm 3.3, \mathrm{n}=8)$ AP. The DV/W ratio ranged from 0.97 to $1.29(1.11 \pm 0.10$, $\mathrm{n}=22)$. The mean diameter of thecal pores was $0.27 \pm 0.04 \mu \mathrm{m}(\mathrm{n}=31)$ and the apical pore plate was $6.3 \pm 0.7 \mu \mathrm{m}$ long (Table 1 ). Plate $1^{\prime}$ exhibited 0.24 pores $\mu \mathrm{m}^{-1}$, plate $6 ", 0.18$ pores $\mu \mathrm{m}^{-1}$, and plate $3^{\prime \prime \prime}, 0.16$ pores $\mu \mathrm{m}^{-1}$ (Table 1). Plate 7" was ornamented with 3-5 pores, and plate 2 "'", with 2-7 pores (Table 1). Cells of C. palmyrensis exhibited lower mean pore density when compared with C. malayensis and C. santacroce (Figures 3, 5 and 6), however, some cells were found containing a greater number of pores, so that an overlapping in pore density and pore number was recorded among the three species (Table 1). Strains of C. palmyrensis were obtained from samples collected in the coast of Pernambuco State and from Abrolhos Archipelago (Table 1, Figure 4).

Table 1. Cell measurements of Coolia spp., in $\mu \mathrm{m}$, as obtained from scanning electron micrographs (SEM). Minimum and maximum values, as well as the number of cells measured (in italics), are provided in parentheses following each average value. DV = dorso-ventral length (depth); W = width; $\mathrm{AP}=$ antero-posterior length (height); $\mathrm{APC}=$ apical pore complex. Pore density (pores $\mu \mathrm{m}^{-1}$ ) was measured using $5 \times 5 \mu \mathrm{m}$ square, placed in the center of the thecal plate.

\begin{tabular}{|c|c|c|c|c|c|}
\hline \multicolumn{2}{|c|}{ Measurement } & C. malayensis & C. santacroce & C. palmyrensis & C. tropicalis \\
\hline \multirow{3}{*}{ Cell size } & DV & $26.7(23.3-29.8,26)$ & $27.6(24.0-30.7,30)$ & $24.1(19.1-28.4,27)$ & $34.1(24.3-39.8,29)$ \\
\hline & W & $24.3(19.6-29.3,13)$ & $26.5(23.2-29.7,26)$ & $22.2(17.4-27.3,29)$ & $32.9(23.6-39.7,29)$ \\
\hline & $\mathrm{AP}$ & $22.0(16.6-25.3,15)$ & $23.8(18.0-30.0,16)$ & $21.0(16.9-26.1,8)$ & $28.0(25.6-31.3,9)$ \\
\hline \multicolumn{2}{|c|}{$\mathrm{DV} / \mathrm{W}$} & $1.12(0.98-1.37,11)$ & $1.05(0.98-1.21,20)$ & $1.11(0.97-1.29,22)$ & $1.08(0.97-1.24,20)$ \\
\hline \multicolumn{2}{|c|}{ APC length } & $6.3(5.3-7.4,13)$ & $5.9(4.9-7.4,8)$ & $6.3(5.5-7.5,8)$ & $7.2(6.3-8.6,9)$ \\
\hline \multicolumn{2}{|c|}{ Pore size } & $0.33(0.26-0.42,36)$ & $0.31(0.25-0.44,40)$ & $0.27(0.23-0.42,31)$ & $0.35(0.27-0.42,31)$ \\
\hline \multirow{3}{*}{ Pore density } & Plate $1^{\prime}$ & $0.30(0.20-0.44,16)$ & $0.29(0.20-0.36,12)$ & $0.24(0.20-0.28,8)$ & $0.23(0.16-0.28,11)$ \\
\hline & Plate 6" & $0.24(0.16-0.32,14)$ & $0.25(0.20-0.32,10)$ & $0.18(0.16-0.20,7)$ & $0.22(0.16-0.28,8)$ \\
\hline & Plate $3^{\prime \prime \prime}$ & $0.18(0.12-0.24,14)$ & $0.22(0.16-0.28,8)$ & $0.16(0.11-0.20,11)$ & $0.22(0.16-0.28,5)$ \\
\hline \multirow{2}{*}{ Pore number } & Plate $7^{\prime \prime}$ & $6.8(4-9,19)$ & $6.9(4-10,13)$ & $4.0(3-5,6)$ & $13.3(7-15,10)$ \\
\hline & Plate $2^{\prime \prime \prime}$ & $5.1(3-8,13)$ & $6.1(4-9,7)$ & $3.5(2-7,8)$ & $9.7(8-12,7)$ \\
\hline \multicolumn{2}{|c|}{$\begin{array}{l}\text { Origin of strains } \\
\text { (Brazilian states) }\end{array}$} & $\begin{array}{c}\text { São Paulo, Rio de } \\
\text { Janeiro, Bahia, } \\
\text { Alagoas and Rio } \\
\text { Grande do Norte }\end{array}$ & $\begin{array}{c}\text { Abrolhos } \\
\text { Archipelago } \\
\text { (Bahia) }\end{array}$ & $\begin{array}{l}\text { Abrolhos } \\
\text { Archipelago } \\
\text { (Bahia) and } \\
\text { Pernambuco }\end{array}$ & $\begin{array}{c}\text { Rio Grande do } \\
\text { Norte }\end{array}$ \\
\hline
\end{tabular}




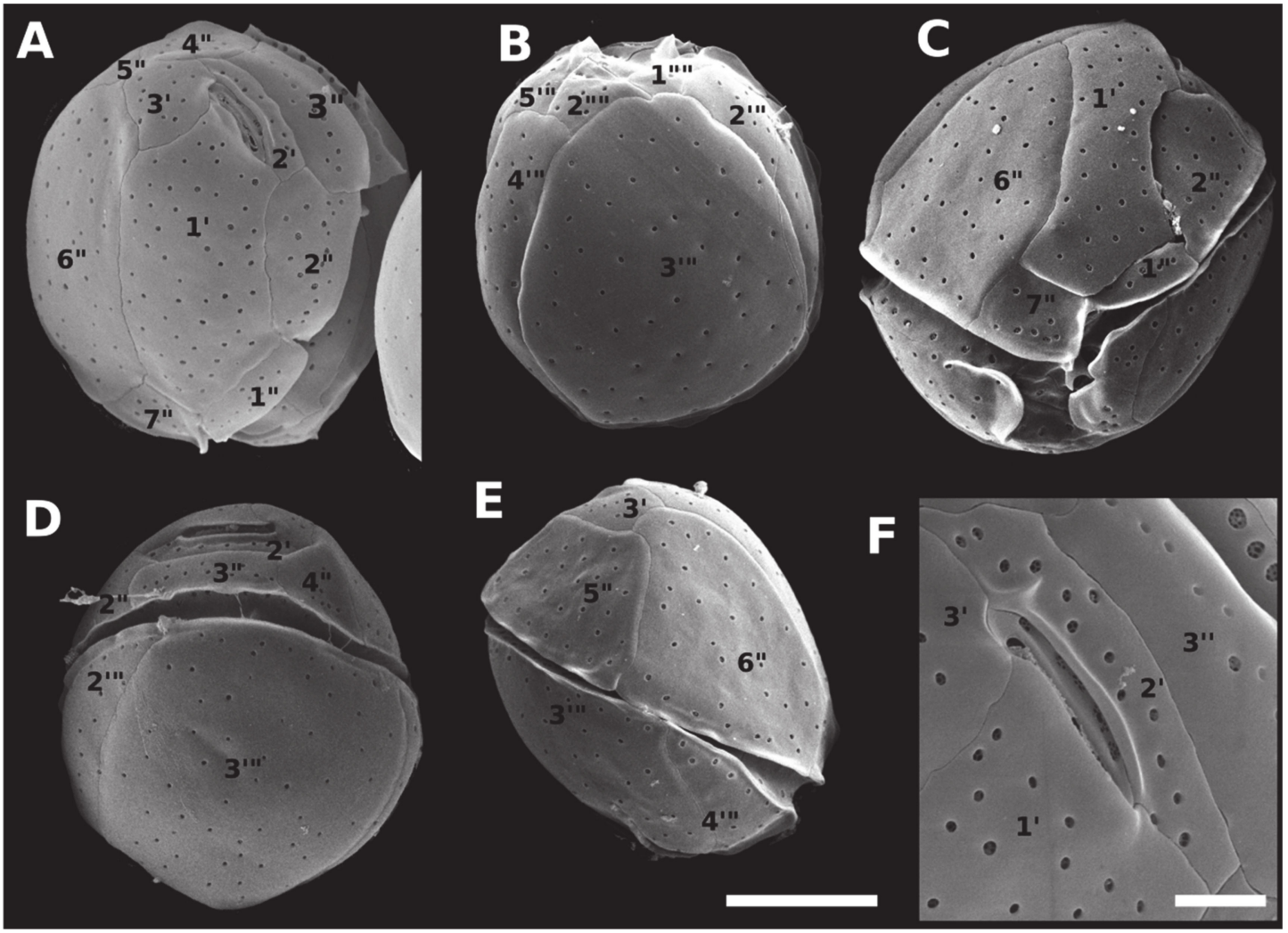

Figure 3. Scanning electron micrographs (SEM) of Coolia malayensis (strain LM-036) cells showing: (A) apical view; (B) antapical view; (C) ventral view; (D) dorsal view; (E) right side view; (F) apical pore complex. Scale bar $=10 \mu \mathrm{m}$, except in $(\mathbf{F})(7.5 \mu \mathrm{m})$.

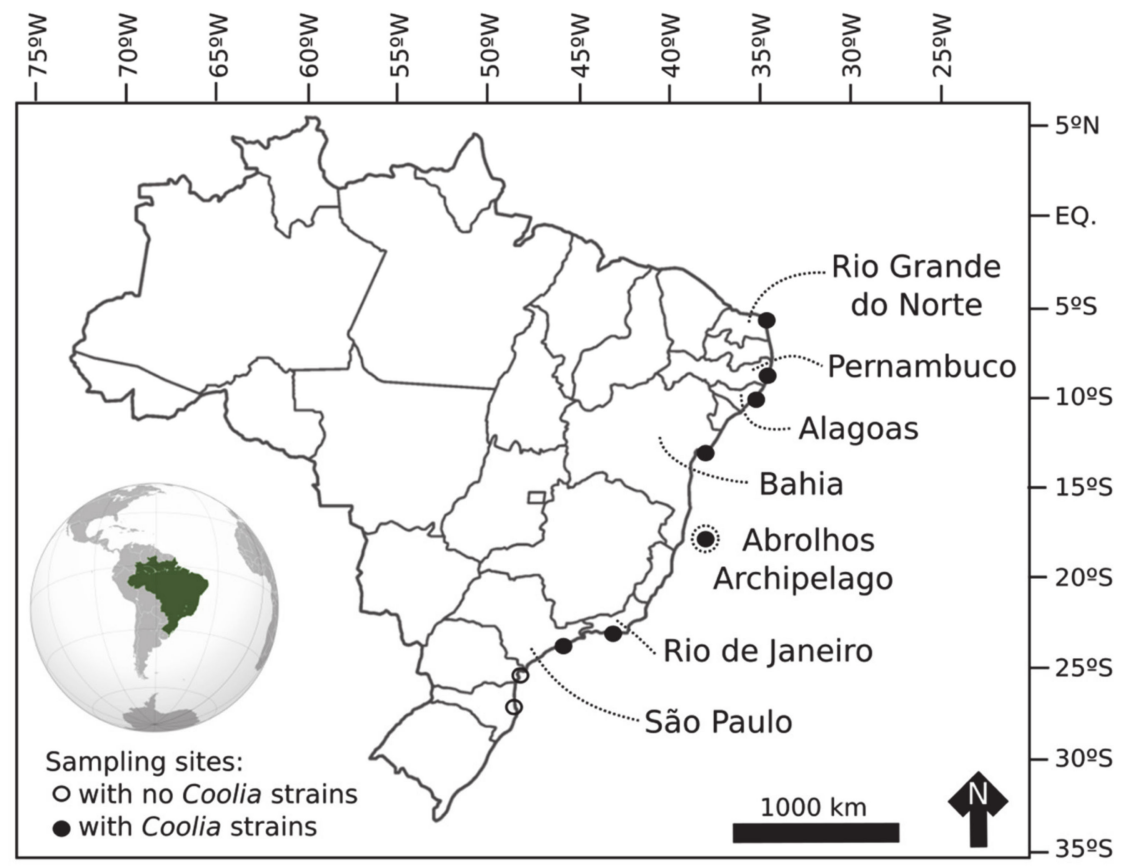

Figure 4. Sampling sites from the present study. Brazilian states and Abrolhos Archipelago (Bahia), where Coolia strains were established from, are indicated. 


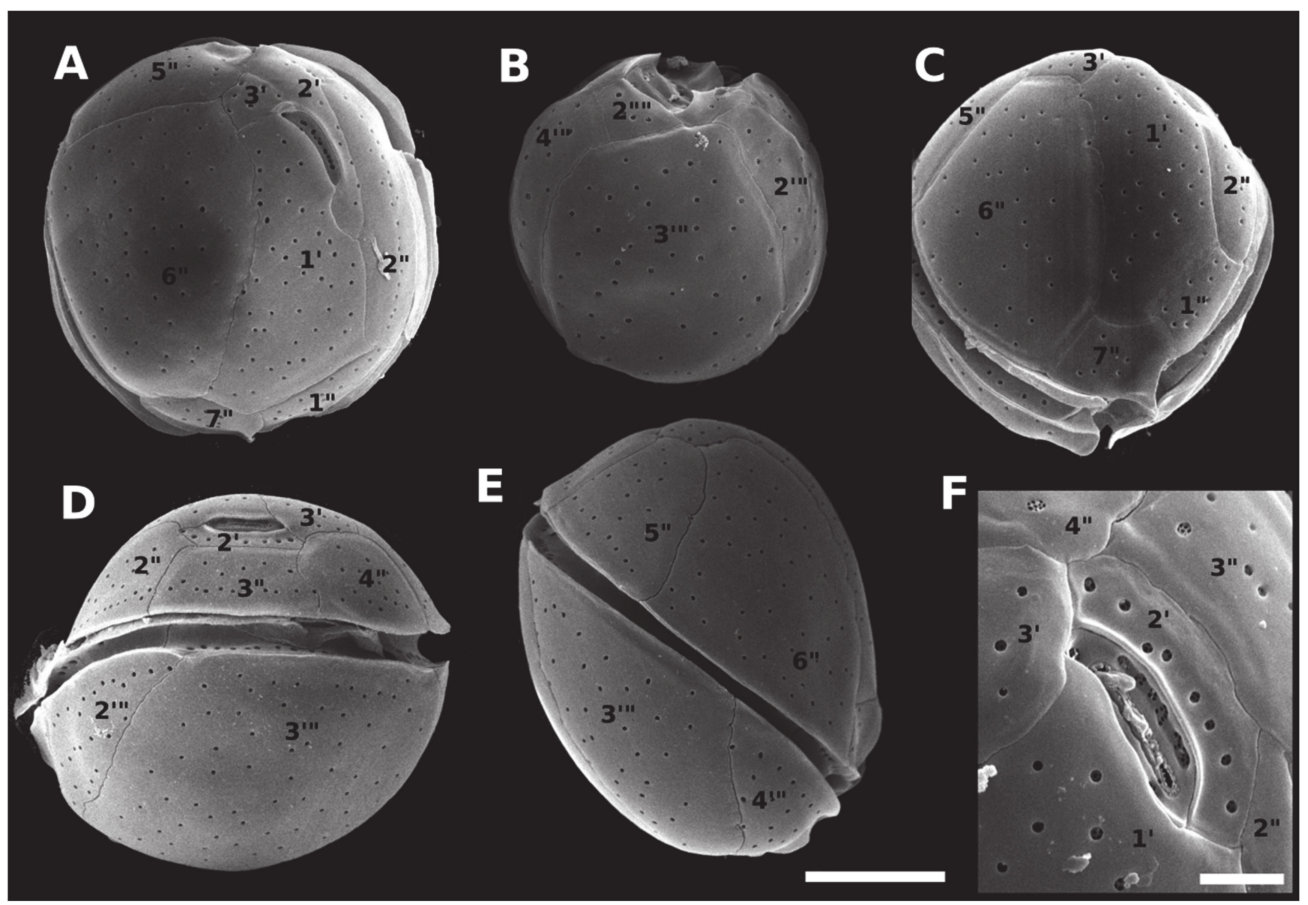

Figure 5. Scanning electron micrographs (SEM) of Coolia santacroce (strain LM-113) cells, showing: (A) apical view; (B) antapical view; (C) apical/ventral view; (D) dorsal view; (E) right side view; (F) apical pore complex. Scale bar $=10 \mu \mathrm{m}$, except in $(\mathbf{F})(7.5 \mu \mathrm{m})$.

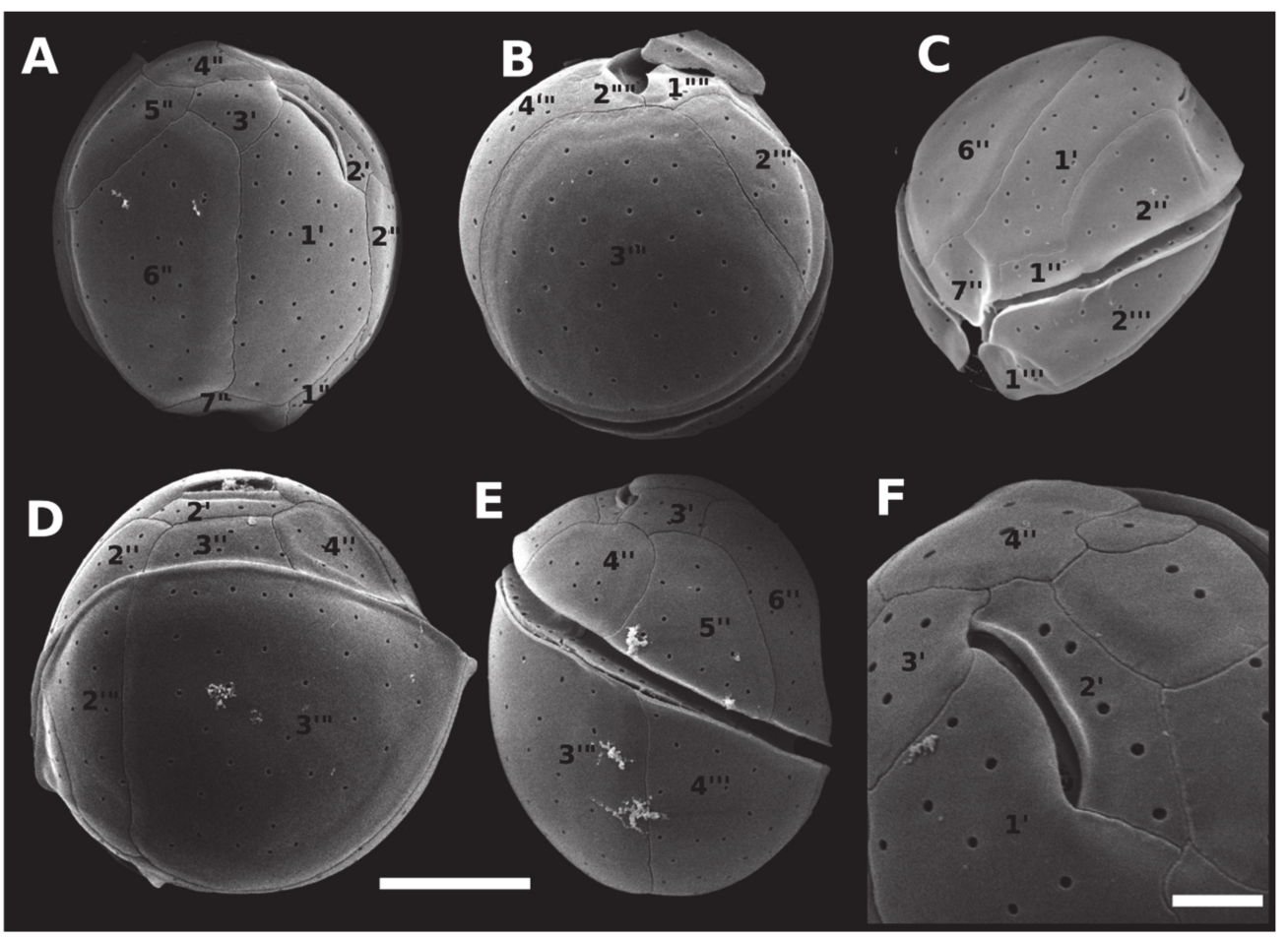

Figure 6. Scanning electron micrographs (SEM) of Coolia palmyrensis (strain LM-076) cells showing: (A) apical view; (B) antapical view; (C) apical/ventral view; (D) dorsal view; (E) right side view; (F) apical pore complex. Scale bar $=10 \mu \mathrm{m}$, except in $(\mathbf{F})(7.5 \mu \mathrm{m})$. 
Cells of C. tropicalis were $24.3-39.8 \mu \mathrm{m}$ in DV $(34.1 \pm 3.3, \mathrm{n}=29), 23.6-39.7 \mu \mathrm{m}$ in $\mathrm{W}(32.9 \pm 3.2$, $\mathrm{n}=29)$ and $25.6-31.3 \mu \mathrm{m}$ in $\operatorname{AP}(28.0 \pm 2.1, \mathrm{n}=9)$. The DV/W ratio was 0.97-1.24 $(1.08 \pm 0.07, \mathrm{n}=20)$. The mean diameter of thecal pores was $0.35 \pm 0.04 \mu \mathrm{m}(\mathrm{n}=31)$ and the apical pore plate was $7.2 \pm 0.8 \mu \mathrm{m}$ long (Table 1). The mean pore densities were 0.23 pores $\mu \mathrm{m}^{-1}$ for plate $1^{\prime}, 0.22$ pores $\mu \mathrm{m}^{-1}$ for plate $6^{\prime \prime}$, and 0.22 pores $\mu \mathrm{m}^{-1}$ for plate $3^{\prime \prime \prime}$ (Table 1 ). Cells of $C$. tropicalis had 7-15 pores in the plate 7" and 8-12 pores in the plate 2"'" (Table 1). This species was easily distinguished from the other three by its elongated, rectangular plate 7" (Figure 7). The only successful cultivated strain of C. tropicalis was obtained from material collected in Pernambuco (Table 1, Figure 4).

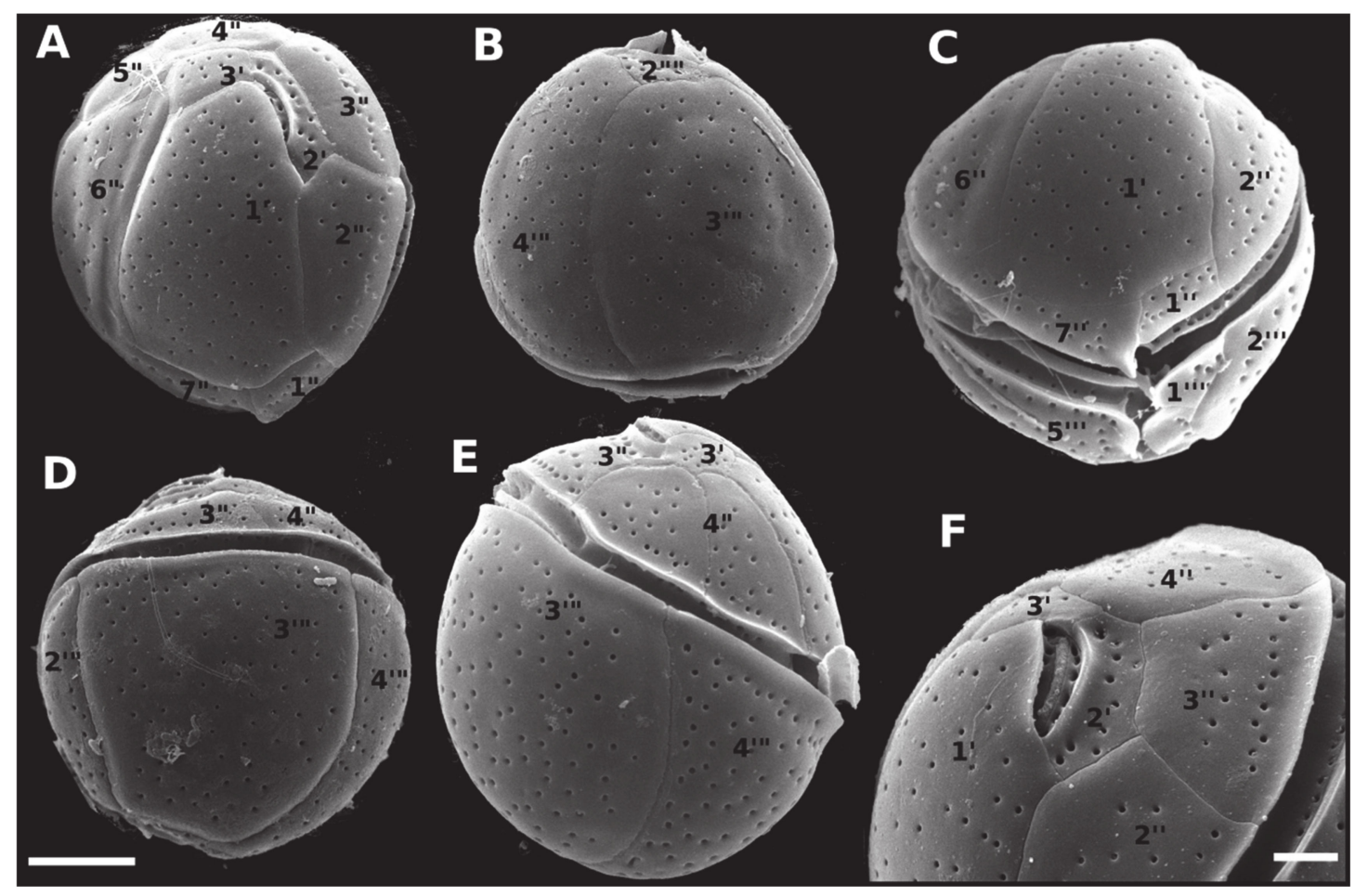

Figure 7. Scanning electron micrographs (SEM) of Coolia tropicalis (strain LM-141) cells showing: (A) apical view; (B) antapical view; (C) ventral view; (D) dorsal view; (E) right side view; (F) apical pore complex. Scale bar $=10 \mu \mathrm{m}$, except in (F) $(7.5 \mu \mathrm{m})$.

\subsection{Toxicity}

Cells Toxicity was evaluated by feeding adults of Artemia salina with increasing biomass of Coolia spp. and proportionally decreasing biomass of a nontoxic algal species (Tetraselmis sp.) In control treatments, all $A$. salina individuals fed only with Tetraselmis sp. survived after $96 \mathrm{~h}$ of experiment, with no signs of impaired swimming or any other visual alteration.

Among individuals fed with increasing biomass of C. palmyrensis (strain LM112) or C. santacroce (LM113), no significant toxic effect was recorded (Figures 8 and 9). On the contrary, exposure to C. malayensis (LM036) and C. tropicalis (LM141) was lethal to A. salina, with mortality rates directly related to biomass and exposure time (Figure 8C,D). C. malayensis killed up to $57 \%$ of $A$. salina individuals after $96 \mathrm{~h}$ of experiment, with no differences in mortality rates among those exposed to biomasses of toxic cells equivalent to $1500 \mathrm{ng} \mathrm{C} \mathrm{ml}^{-1}$ or higher (Figure 8C). C. tropicalis, in turn, caused significantly increasing mortality rates with increasing biomass of toxic cells and exposure time, killing $>90 \%$ of the individuals after $72-96 \mathrm{~h}$ of exposure to the highest biomass tested $\left(16,000 \mathrm{ng} \mathrm{C} \mathrm{ml}^{-1}\right)$ (Figure 8D). After $24 \mathrm{~h}$, mortality rates caused by $C$. tropicalis were consistently higher than those provoked by equivalent biomass of $C$. malayensis at the same exposure time (Figures 8 and 9). 

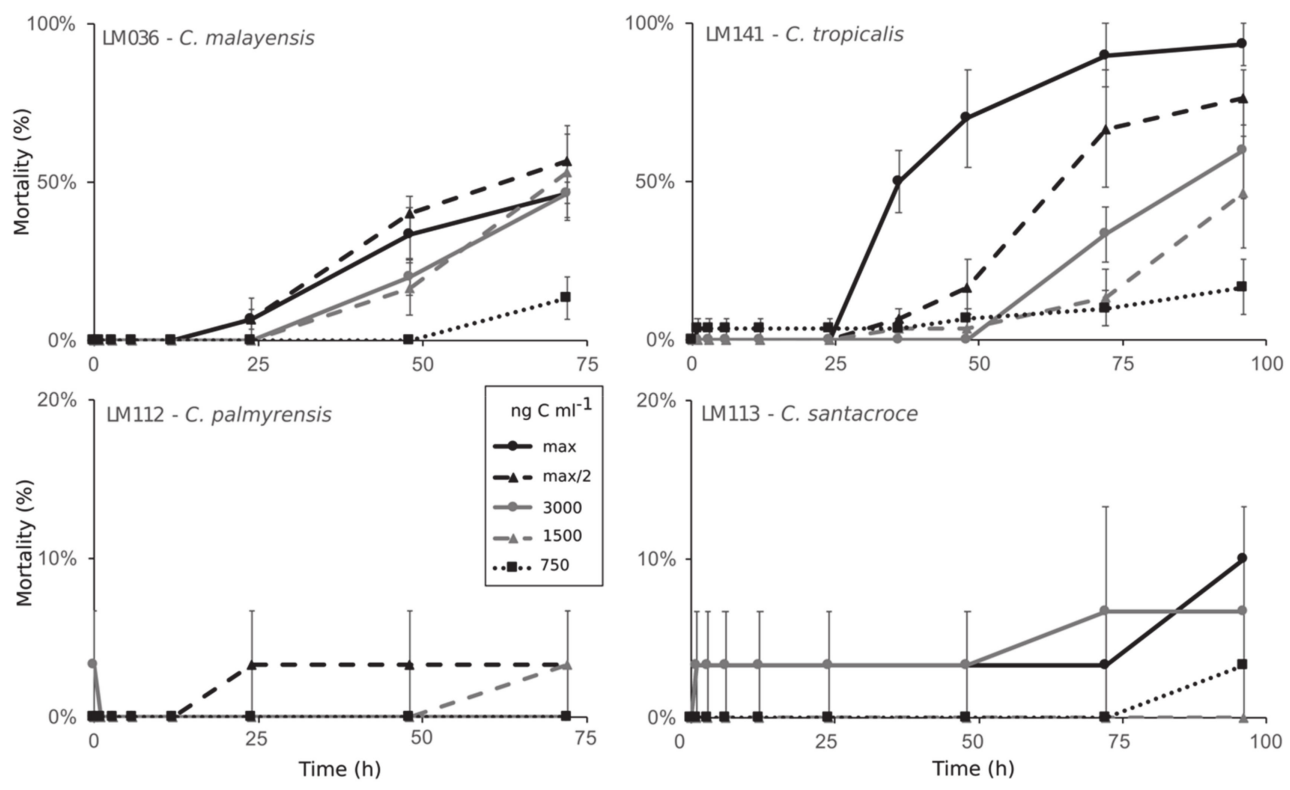

Figure 8. Lethality (\%) of Coolia spp. to adults of Artemia salina over $96 \mathrm{~h}$ of exposure. Data series represent different biomass of the toxic algae, expressed as nanograms of carbon per mL. Maximum biomass (max) tested was 19,300 $\mathrm{ng} \mathrm{C} \mathrm{mL}^{-1}$ for C. malayensis, 16,000 $\mathrm{ng} \mathrm{C} \mathrm{mL}^{-1}$ for C. tropicalis, $15,000 \mathrm{ng} \mathrm{C} \mathrm{mL}^{-1}$ for $C$. santacroce, and $11,500 \mathrm{ng} \mathrm{C} \mathrm{mL}^{-1}$ for $C$. palmyrensis. Half of the maximum biomass was also tested (max/2), as well as three fixed biomasses: 3000,1500 and $750 \mathrm{ng} \mathrm{C} \mathrm{mL} L^{-1}$.

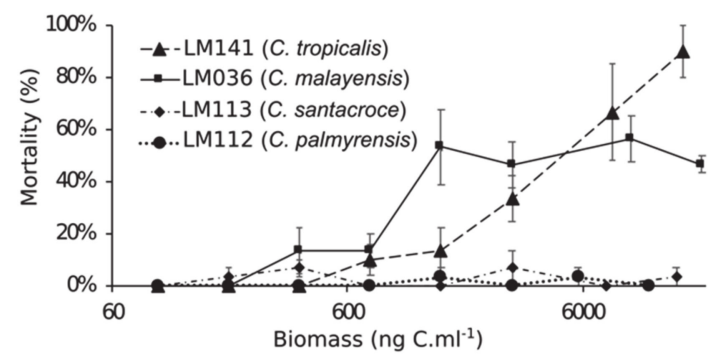

Figure 9. Comparative results of Coolia toxicity assays on adults of Artemia salina, expressed by the lethal effect (\%) after $72 \mathrm{~h}$. Data series represent different species/strains tested.

2.4. Toxin Analysis in Coolia spp. Using Low and High Resolution Mass Spectrometry, and Discovery of Gambierone Toxins in C. tropicalis

\subsubsection{Screening of Coolia spp. Extracts Using High Resolution Mass Spectrometry (System A)}

Fourteen strains of Coolia spp. were analyzed in negative $\left(\mathrm{ESI}^{-}\right)$and positive $\left(\mathrm{ESI}^{+}\right)$full scan ionization mode on a high-resolution Q-Tof 6550 instrument. Raw data were processed following the Find by Formula $(\mathrm{FbF})$ algorithm in the Agilent MassHunter Qualitative Analysis software, using a Personal Compound Database and Library (PCDL) created by Phycotoxins Laboratory (IFREMER, France). The in-house database used for Coolia spp. screening was composed of 81 compounds, including cooliatoxins, yessotoxins, ciguatoxins, maitotoxins, gambieric acids, gambierones, gambierol and gambieroxide (see Supplementary Material, Table S1). Screening with the PCDL allowed identification of compounds based on their formulae and thus detection of the compound itself or isomers. 
In $\mathrm{ESI}^{+}$mode, two compounds were tentatively identified in C. tropicalis (strain LM141) as 44-methyl gambierone (MTX-3) at 6.0 and 6.6 min retention time (RT), with a score of $>90 \%$ and a mass error of $<5$ ppm (Figure 10A). The analysis in $\mathrm{ESI}^{-}$mode confirmed the presence of the same two compounds at 6.0 and $6.6 \mathrm{~min}$ RT in C. tropicalis, identified as 44-methylgambierone with a score of $>90 \%$ and a mass error of $<10$ ppm (Supplementary Material, Figure S1). These compounds were additionally investigated in an extract of Gambierdiscus autrales, used here as reference, as no analytical standard is available. The peak at RT $=6.6 \mathrm{~min}$ assigned to 44-methylgambierone was also present in G. australes, but no other peak was detected. The identity of peak at RT $=6.0 \mathrm{~min}$ in C. tropicalis extract was further determined as a new isomer of 44-methyl gambierone, as detailed below in Section 2.4.2. The assigned positive and negative HRMS ion species for these two compounds are listed in Table 2.

No other known compounds were successfully identified (i.e., with a score $>90 \%$ and a mass error $<10 \mathrm{ppm}$ ) in any of the other thirteen Coolia strains, neither in positive nor in negative mode.

Table 2. HRMS ion species corresponding to the accurate mono-isotopic $m / z$ for 44 -methyl gambierone and its isomer. Mass differences $(\Delta \mathrm{ppm})$ were compared between measured and exact theoretical mass.

\begin{tabular}{ccc}
\hline Ion Species (Mono-Isotopic $m / z$ ) & $\begin{array}{c}\text { 44-Methyl Gambierone } \\
\text { RT }=\mathbf{6 . 6} \text { min }\end{array}$ & $\begin{array}{c}\text { 44-Methyl Gambierone Isomer } \\
\text { RT }=\mathbf{6 . 0} \text { min }\end{array}$ \\
\hline$[\mathrm{M}+\mathrm{H}]^{+}$ & $1039.4959(-2.1)$ & $1039.4952(+2.0)$ \\
{$\left[\mathrm{M}+\mathrm{H}-\mathrm{H}_{2} \mathrm{O}\right]^{+}$} & $1021.4844(+0.9)$ & $1021.4837(+3.3)$ \\
{$[\mathrm{M}+\mathrm{Na}]^{+}$} & $1061.4706(-2.1)$ & $1061.4757(+0.4)$ \\
{$[\mathrm{M}+\mathrm{K}]^{+}$} & $1077.4398(-8.5)$ & $1077.4423(-6.2)$ \\
{$[\mathrm{M}-\mathrm{H}]^{-}$} & $1037.4797(+1.1)$ & $1037.4766(-1.9)$ \\
{$\left[\mathrm{M}-\mathrm{H}-\mathrm{H}_{2} \mathrm{O}\right]^{-}$} & $1019.4651(-2.8)$ & $1019.4587(-9.1)$ \\
\hline
\end{tabular}

2.4.2. Comparative Fragmentation Between 44-Methyl Gambierone and the New 44-Methyl Gambierone Isomer

As the FbF workflow procedure is not sufficient to unequivocally identify a compound, HRMS/MS spectral acquisition in both $\mathrm{ESI}^{-}$and $\mathrm{ESI}^{+}$mode were necessary to confirm that the new compound was in fact an isomer of 44-methyl gambierone.

In $\mathrm{ESI}^{-}$, fragmentation of the molecular anion $[\mathrm{M}-\mathrm{H}]^{-}$at $m / z 1037.4785$ showed that both molecules shared the same product ions (Table 3, Figure S2). The fragments at $m / z$ 899.3741 [C43H63O18S]- and 96.9601 [HOSO3], which exhibited very small mass error $(\Delta \mathrm{ppm}<3)$ in our analysis, corresponded to the two fragments also described in previous studies $[5,35]$.

The compound with RT at 6.0 min was further confirmed as an isomer of 44-methyl gambierone, by comparing the positive HRMS/MS with that of 44-methyl gambierone itself (Table 3, Figure 10B). Indeed, the fragmentation pathways showed the formation of protonated fragment ions with a small mass error $(\Delta \mathrm{ppm}<5 \mathrm{ppm})$ at $m / z$ 959.5330, 941.5216, 923.5133, 905.5012 and 887.4945, corresponding to the sulfite loss followed by successive water losses. Furthermore, similar fragmentation patterns were observed from $\mathrm{m} / \mathrm{z} 303$ to 95 for both compounds, and the gambierone specific fragment ion was detected at $m / z 109.0645$, in the isomer as well $(\Delta \mathrm{ppm}=-2.7)$. 
Table 3. List of assigned HRMS/MS fragment ions for 44-methyl gambierone and its isomer obtained from $\mathrm{MS}^{2}$ spectra of $[\mathrm{M}+\mathrm{H}]^{+}$at $\mathrm{m} / z 1039.4931$ for $\mathrm{ESI}^{+}$, and of $[\mathrm{M}-\mathrm{H}]^{-}$at $\mathrm{m} / \mathrm{z} 1037.4785$ for $\mathrm{ESI}^{-}$. The $\mathrm{m} / \mathrm{z}$ values correspond to the accurate mono-isotopic $m / z$.

\begin{tabular}{|c|c|c|c|c|c|c|}
\hline \multirow{2}{*}{$\begin{array}{l}\text { Parent or Fragment } \\
\text { Ion }\end{array}$} & \multirow{2}{*}{ Formula } & \multicolumn{2}{|c|}{ 44-Methyl Gambierone } & \multicolumn{2}{|c|}{ 44-Methyl Gambierone Isomer } & \multirow{2}{*}{ Ref. } \\
\hline & & $(m / z)$ & $\Delta \mathrm{ppm}$ & $(m / z)$ & $\Delta$ ppm & \\
\hline Parent ion $[\mathrm{M}+\mathrm{H}]^{+}$ & $\mathrm{C}_{52} \mathrm{H}_{79} \mathrm{O}_{19} \mathrm{~S}^{+}$ & 1039.4909 & -2.1 & 1039.4952 & +2.0 & \\
\hline \multirow{14}{*}{$\begin{array}{c}\mathrm{ESI}^{+} \\
\text {Fragment ions }\end{array}$} & $\mathrm{C}_{52} \mathrm{H}_{77} \mathrm{O}_{18} \mathrm{~S}^{+}$ & 1021.4834 & +0.9 & 1021.4859 & +3.3 & \multirow{7}{*}[5]{} \\
\hline & $\mathrm{C}_{52} \mathrm{H}_{75} \mathrm{O}_{17} \mathrm{~S}^{+}$ & 1003.4773 & +5.3 & 1003.4750 & +3.0 & \\
\hline & $\mathrm{C}_{52} \mathrm{H}_{79} \mathrm{O}_{16}{ }^{+}$ & 959.5364 & +0.1 & 959.5330 & -3.4 & \\
\hline & $\mathrm{C}_{52} \mathrm{H}_{77} \mathrm{O}_{15}^{+}$ & 941.5254 & -0.3 & 941.5216 & -4.4 & \\
\hline & $\mathrm{C}_{52} \mathrm{H}_{75} \mathrm{O}_{14}^{+}$ & 923.5175 & +2.5 & 923.5133 & -2.0 & \\
\hline & $\mathrm{C}_{52} \mathrm{H}_{73} \mathrm{O}_{13}+$ & 905.5004 & -4.6 & 905.5012 & -3.7 & \\
\hline & $\mathrm{C}_{52} \mathrm{H}_{71} \mathrm{O}_{12}{ }^{+}$ & 887.4902 & -4.3 & 887.4945 & +0.6 & \\
\hline & $\mathrm{C}_{43} \mathrm{H}_{65} \mathrm{O}_{18} \mathrm{~S}^{+}$ & 901.3847 & -4.3 & 901.3880 & -0.7 & \multirow{7}{*}{ [36] } \\
\hline & $\mathrm{C}_{43} \mathrm{H}_{63} \mathrm{O}_{14}^{+}$ & 803.4191 & -2.7 & 803.4237 & +3.1 & \\
\hline & $\mathrm{C}_{15} \mathrm{H}_{21} \mathrm{O}_{2}^{+}$ & 233.1551 & +6.4 & 233.1544 & +3.4 & \\
\hline & $\mathrm{C}_{15} \mathrm{H}_{19} \mathrm{O}^{+}$ & 215.1438 & +3.5 & 215.1443 & +5.9 & \\
\hline & $\mathrm{C}_{8} \mathrm{H}_{11} \mathrm{O}^{+}$ & 123.0802 & -2.0 & 123.0810 & -5.2 & \\
\hline & $\mathrm{C}_{7} \mathrm{H}_{9} \mathrm{O}^{+}$ & 109.0652 & +3.8 & 109.0645 & -2.7 & \\
\hline & $\mathrm{C}_{7} \mathrm{H}_{11}{ }^{+}$ & 95.0855 & -0.3 & 95.0854 & -1.3 & \\
\hline Parent ion $[\mathrm{M}-\mathrm{H}]^{-}$ & $\mathrm{C}_{52} \mathrm{H}_{77} \mathrm{O}_{19} \mathrm{~S}^{-}$ & 1037.4797 & +1.1 & 1037.4766 & -1.9 & \\
\hline ESI $^{-}$ & $\mathrm{C}_{43} \mathrm{H}_{63} \mathrm{O}_{18} \mathrm{~S}^{-}$ & 899.3743 & +0.3 & 899.3732 & -1.0 & \multirow{2}{*}{ [35] } \\
\hline Fragment ions & {$\left[\mathrm{HOSO}_{3}\right]^{-}$} & 96.9601 & 0 & 96.9599 & -2.1 & \\
\hline
\end{tabular}



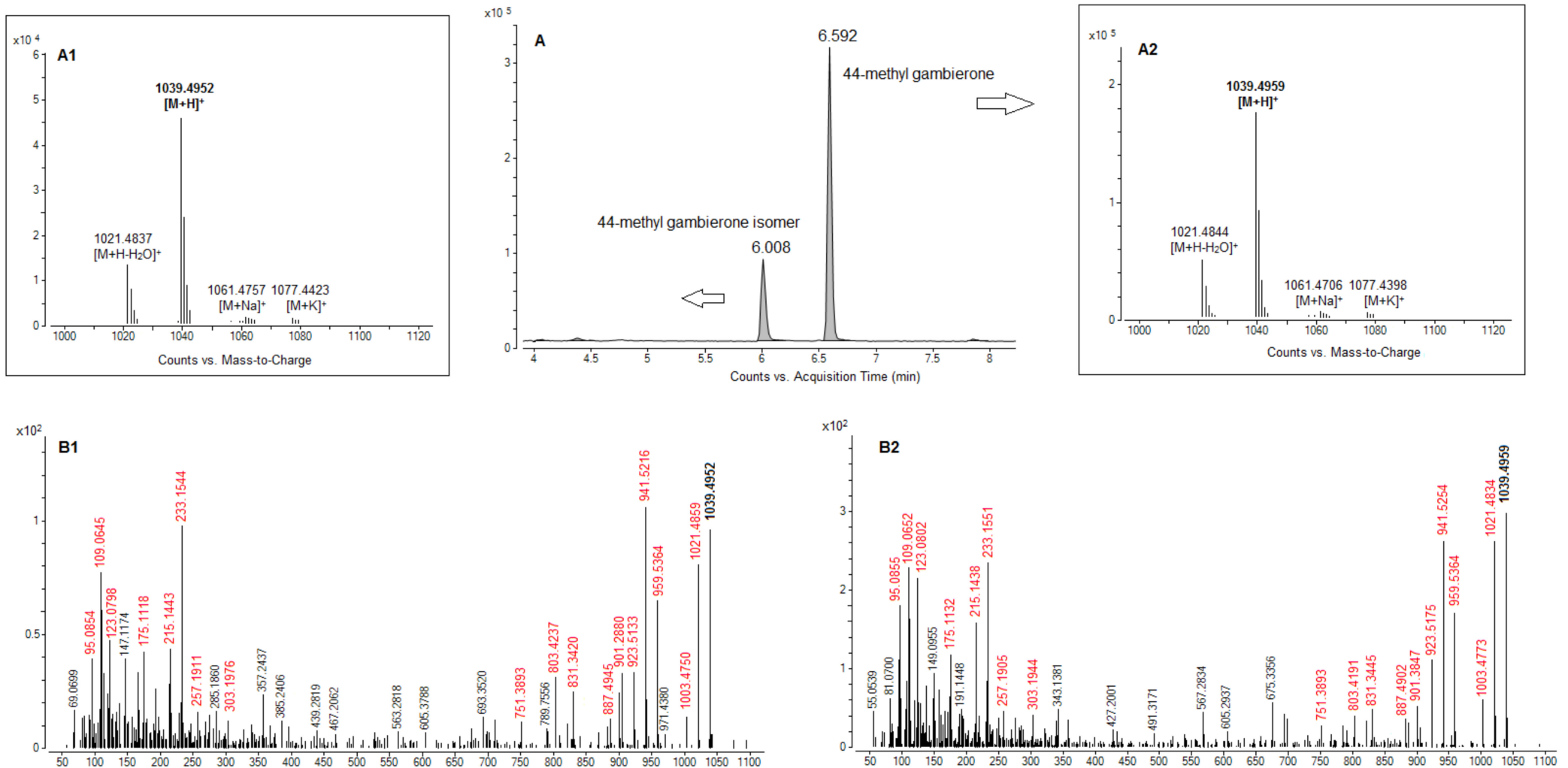
Counts vs. Mass-to-Charge $(m / z)$

Counts vs. Mass-to-Charge (m/z)

Figure 10. (A) LC-HRMS chromatogram (system A) of C. tropicalis extract and high resolution full scan mass spectra acquired in positive mode on the apex of the peak at (A1) $6.008 \mathrm{~min}$ for 44-methyl gambierone isomer and (A2) at $6.592 \mathrm{~min}$ for 44-methyl gambierone. HRMS/MS spectra of $[\mathrm{M}+\mathrm{H}]^{+}(\mathrm{m} / \mathrm{z} 1039.4931)$ for (B1) 44-methyl gambierone isomer at $6.008 \mathrm{~min}$ and for (B2) 44-methyl gambierone at $6.592 \mathrm{~min}$, resulting from an average of three collision energies (15, 30 and 45 eV). Fragments common to both compounds were marked in red in the mass spectrum and reported in Table 3. 


\subsubsection{Quantification of Gambierone Toxins with LC-LRMS/MS (System B) in C. tropicalis}

The extract of Coolia tropicalis (strain LM141) was further analyzed on a low-resolution API4000 Qtrap instrument, in order to confirm the previous results and to quantify the gambierone toxins (Figure 11). A targeted MRM method was performed in negative ionization mode for the screening of MTXs, gambierones and gambieric acids, as described in Section 5.5.2. Retention times (RTs) were slightly shorter in system B compared to system A, due to differences in dead volumes of the UHPLC systems. The strain of $C$. tropicalis contained 73 and 20 pg MTX-1 eq. cell ${ }^{-1}$ of 44 -methylgambierone and 44-methylgambierone isomer, respectively. Therefore, under the culture conditions described in Section 5.1, this C. tropicalis strain contained 3.6-fold greater intracellular amounts of 44-methyl gambierone than those of its isomer.

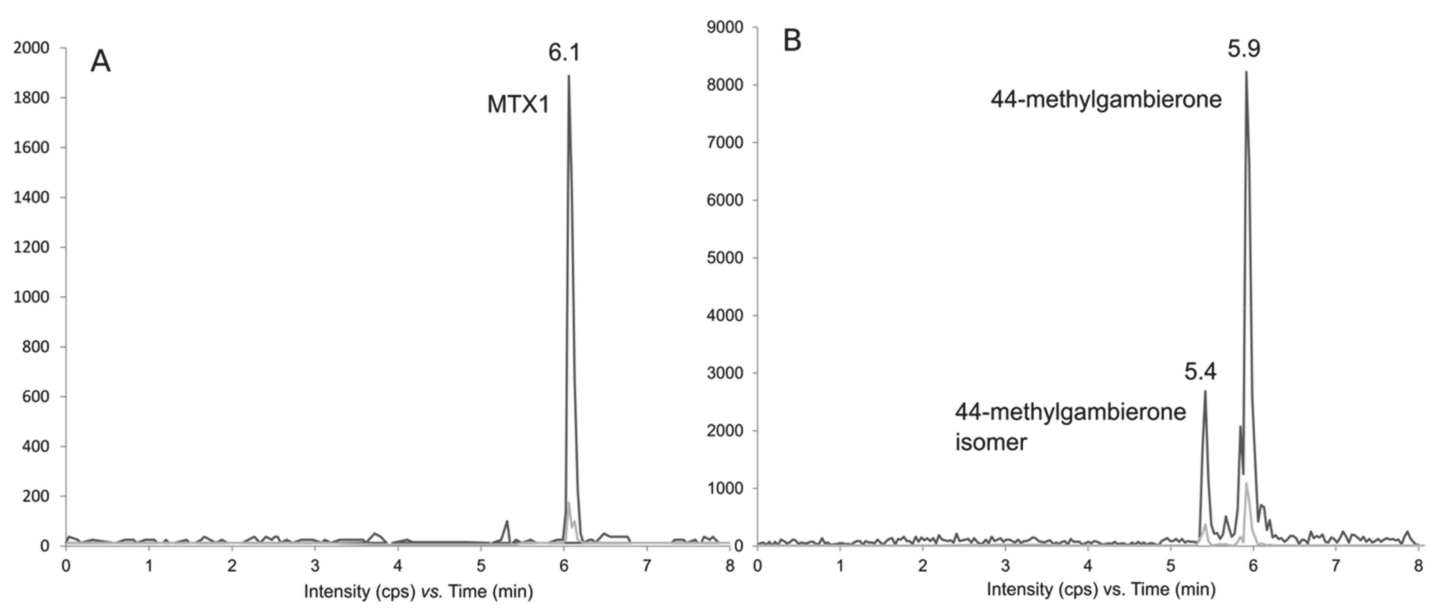

Figure 11. LC-MS/MS Chromatograms acquired in negative MRM mode (system B) of (A) MTX1 standard solution at a concentration of $500 \mathrm{ng} \mathrm{mL}^{-1}$ (Wako, Japan) and (B) 44-methyl gambierone at $5.93 \mathrm{~min}$ and the new isomer at $5.42 \mathrm{~min}$ in Coolia tropicalis extract.

\section{Discussion}

\subsection{Taxonomy and Phylogeny of Coolia Species}

Coolia is usually considered a harmful genus of benthic dinoflagellates [1], even though marked species-specific differences in toxicity are observed, as reported herein and discussed later in Section 3.3. Therefore, accurate taxonomy is desirable before any toxicological discussion concerning Coolia spp. For instance, prior to the description of $C$. malayensis, and without performing genetic analysis, the occurrence of toxic (CAWD77) and non-toxic (CAWD39 and CCMP304) strains of C. monotis was reported in New Zealand [31]. However, by retrieving genetic sequences of the same strains from GenBank, it is possible to find out that two out of three strains belonged, in fact, to C. malayensis, and that the actual C. monotis strain (CCMP304) was non-toxic. In the present study, before screening our strains for the presence of toxic compounds and toxic effects, we thus assessed Coolia spp. taxonomy based on morphology and genetic data, with special focus on the two most toxic species, i.e., C. malayensis and C. tropicalis.

From all eight species of Coolia described so far, only one (C. areolata) has no molecular data available to date [15]. Genetic separation among the species is, in general, well resolved. Despite several studies suggesting that $C$. malayensis and $C$. monotis might be the same species [1,37], currently the separation into two different species is more widely accepted [14,19]. In the present study, the phylogenetic analysis on Brazilian strains of Coolia spp. revealed similar topology to previous investigations, clearly separating all species based on both ITS (ITS-1, 5.8S rDNA, ITS-2) and LSU (D1-D3) sequences. However, these two DNA fragments resulted in distinct relative distances separating both C. palmyrensis 
and C. canariensis from the other species. Thus, we strongly recommend that phylogenetic analyses of Coolia include at least two markers in order to confirm species identification.

As previously described, Coolia species can be morphologically separated into two major groups based on the shape of the seventh pre-cingular plate ( $\left.7^{\prime \prime}\right)[14,15,28]$. Coolia monotis, C. malayensis (Figure 3C), C. palmyrensis and C. santacroce possess a short quadrangular (sometimes triangular) 7" plate, and the suture $7 " / 1^{\prime}$ is short [14,19]. In contrast, Coolia tropicalis (Figure 7C), C. canariensis, C. guanchica and C. areolata exhibit a rectangular 7" plate. In this case, the suture between $7^{\prime \prime}$ and the first apical plate $\left(1^{\prime} ; 7^{\prime \prime} / 1^{\prime}\right)$ is elongated $[15,16,23,25]$.

The species group encompassing $C$. tropicalis is characterized by a larger cell size compared to the C. monotis group (present study, Table $1 ;[15,16,18,19])$. Both species groups are also distinguishable phylogenetically, based on the LSU D1-D3 alignment dataset (see Figure 2). Furthermore, C. tropicalis is easily separated from the other species within its own group (i.e., those possessing a rectangular 7 " plate), based on the smooth cell surface on both epitheca and hypotheca (present study, Figure 7A-B; $[15,23,28]$ ).

Conversely, species within the $C$. monotis group are difficult to separate from each other based solely on morphological features. Plate arrangements are quite similar, size ranges overlap, and thecal plates lack any kind of perforation patterns in these smaller-celled species. For C. malayensis, a larger third post-cingular plate ( $\left.3^{\prime \prime \prime}\right)$ is the most noticeable feature distinguishing it from other species from C. monotis group. In fact, we did observe this feature in most of the cells examined in this study. However, its use as diagnostic of C. malayensis may be questionable, as plate $3^{\prime \prime \prime}$ can be, in some cases, similar in size to plate 4 "' (present study, $[27,38]$ ). As an additional complicating issue, measuring a large plate like $3^{\prime \prime \prime}$ can be inaccurate due to the pronounced cell curvature, making it inappropriate to base cell identification on morphometrics in this case. Alternatively, each of the species from C. monotis group could be differentiated from C. malayensis, based on a particular feature. C. palmyrensis, for instance, may be easily separated from other species based on the density and number of pores on the cell surface [19]. In the present study, we confirmed that $C$. palmyrensis had a lower pore density than its sister species C. malayensis and C. santacroce (Table 1). However, as previously reported [19], some variability exists, and the ranges of both pore numbers and density can overlap between species. In this sense, C. malayensis may sometimes possess low pore density, thus mimicking C. palmyrensis, and vice versa (Table 1). Such inconstant thecae features can be attributed to natural variability inside the population, deformation due to culture conditions or to the cell-cycle phase [38]. In conclusion, as already indicated for $C$. monotis and C. santacroce [20], species identification within this group of species (C. monotis group) should always be supported by genetic data, as otherwise, it can lead to misidentification.

\subsection{Species Distribution and Diversity in Brazil}

Until quite recently, the distribution of benthic dinoflagellates was poorly documented in Brazilian waters, with the genus Coolia, represented at that time by C. malayensis, found exclusively along the southeastern coast [21]. Recent studies, however, have documented a larger number of species (C. malayensis, C. tropicalis and C. canariensis), occurring over a wider geographical distribution, including the south [12], southeast $[26,28]$ and northeast $[27,28]$ sectors of the Brazilian coast. In the present study, we reported for the first time the species $C$. santacroce and C. palmyrensis occurring in South Atlantic waters, and confirmed the high genetic diversity of this genus in Brazil, as suggested by Nascimento et al. [28] Similar species composition has been found in the Canary Islands [15,23], suggesting a high degree of connectivity over the Atlantic Ocean.

The most widely distributed species in Brazil is C. malayensis, present along the entire coast (present study, [12,26-28]). The other toxic species reported herein, C. tropicalis, is more restricted to the northeastern warm waters (present study) and the tropical oceanic island of Trindade [28]. The other three species, C. canariensis [28], C. santacroce and C. palmyrensis (present study), were found exclusively in offshore sites: Trindade Island for C. canariensis, Abrolhos Archipelago for C. santacroce and C. palmyrensis, and an offshore diving site in Pernambuco State for C. palmyrensis. Similar patterns 
of species distribution have been observed in Australia [22] and in the Iberian Peninsula [24], with C. malayensis more broadly distributed, C. tropicalis restricted to warmer waters, and C. palmyrensis present in offshore sites. Coolia santacroce, in turn, had only been recorded, so far, in the Caribbean Sea (GenBank sequences). Thus, a general pattern of Coolia spp. distribution seems to arise from this and previous studies: C. malayensis is globally distributed (see [14]); C. monotis is probably broadly distributed in coastal waters of Europe and the East Atlantic [24]; while distributions of $C$. tropicalis, C. canariensis, C. santacroce and C. palmyrensis are more restricted, mainly to warmer waters and/or to offshore sites with lower hydrodynamics (present study, [22]).

\subsection{Toxicity and Toxin Production}

Toxicity within the genus Coolia (as Coolia sp.) was first reported in the early 1980s, based on hemolytic activity via in vitro assays, although no toxicity to mice and fish was registered for the same methanol extract [29]. Since then, this genus of benthic dinoflagellates has been considered potentially toxic [1]. However, later studies did not detect any toxic activity in several strains/species, using different cell models and organisms. For instance, ethanol extracts of cell pellets of $C$. monotis (strain CCMP304) or C. malayensis (CAWD39) were not toxic to mice following intraperitoneal injections in mouse bioassays (MBA) [31]. Additionally, Penna et al. [33] tested methanol extracts of $C$. monotis (strain CM2V) and C. malayensis (strain CCMP1345), and did not find any hemolytic activity to human erythrocytes. Similarly, methanol extracts of other C. monotis strains (CCMP2582 and CCMP304) exhibited no cytotoxicity to Rhabdomyosarcoma cells derived from bone marrow [19]. Moreover, Artemia franciscana nauplii were not affected upon exposure to living cells of $C$. monotis (strains Dn23EHU, DN24EHU) or C. canariensis (strains Dn28EHU, Dn29EHU) [34], and no toxic effects were observed in A. salina nauplii exposed to filtered medium of C. guanchica cultures [15]. In the present study, likewise, no toxic effects were observed in adults of $A$. salina exposed to increasing abundances of living C. santacroce or $C$. palmyrensis cells. In contrast, cells of $C$. malayensis and $C$. tropicalis were lethal to the micro-crustaceans at equivalent biomass ranges (see Figure 8), confirming the marked species-specific variability in Coolia toxicity.

After the early study by Nakajima et al. [29], Holmes et al. [30] evaluated the toxicity of $C$. tropicalis (as C. monotis) using MBA. The authors reported mouse mortality caused by the butanol-soluble fraction of the extract, but no toxicity from either hexane- or water-soluble fractions. Later on, acetone and ethanol extracts from two different C. malayensis strains (CAWD77 and CAWD151) were also lethal to mice via MBA [31,39]. Moreover, C. malayensis (methanol extracts) exhibited the strongest cytotoxic effects to Rhabdomyosarcoma cells when compared to C. santacroce (intermediate toxicity) and C. palmyrensis (low toxicity) [19]. Finally, methanol extracts from Brazilian strains of both C. malayensis (UFBA044) and C. tropicalis (UFBA055) showed hemolytic activity to sheep erythrocytes [27]. These are the same species here reported as lethal to A. salina upon short-term (24-96 h) exposure to living cells. In our experiments, a northeastern Brazilian strain of $C$. tropicalis (LM141) was relatively more toxic than a C. malayensis strain isolated from the southeastern coast (LM036).

Taking the results from this and previous toxicity assessments together, we believe that at least C. tropicalis and C. malayensis should be considered toxic species. Toxicity of other Coolia species may vary geographically and should be more carefully evaluated, perhaps using a combination of different assays. For example, C. santacroce and C. palmyrensis strains from the Caribbean or the Pacific Ocean (Palmyra Atoll) were reported as cytotoxic by Karafas et al. [19], but strains from the present study were not lethal to $A$. salina. Nevertheless, considering only genetically sequenced strains, C. monotis, C. canariensis and C. guanchica have not shown, up to now, any sign of toxic activity (see discussion above), while the toxicity of $C$. areolata has not been examined [25].

The compounds responsible for the toxic activity in C. malayensis and C. tropicalis are still controversial. In 1995, an analogue of yessotoxin (YTX), then named cooliatoxin, was described in C. tropicalis (as C. monotis) using low-resolution LC-MS/MS [30]. The exact molecular structure of that compound, however, was not elucidated. Later on, related, yet unique, compounds with fewer oxygen 
atoms than cooliatoxin or YTX were detected in C. malayensis from Okinawa (Japan), and described as disulphated polyether analogues of YTX based on high-resolution LC-MS/MS [32]. However, YTX analogues (including cooliatoxin) have never been detected again in other Coolia spp. cultures (present study, [23]). Besides YTX analogues, our strains of C. malayensis, C. palmyrensis and C. santacroce also lacked any other toxic compound produced by another genus of benthic dinoflagellates, Gambierdiscus, including maitotoxins, gambierones, gambieroxide, and gambieric acids. A strain of C. tropicalis, however, contained relatively high intracellular levels of 44-methyl gambierone (previously referred to as MTX-3 [35]) and a novel isomer of the same compound. Spectral data presented by Holmes et al. [30] suggest that 44-methyl gambierone was not present in that extract (absence of 1037.5 in the negative ionspray mass spectrum), suggesting either misidentification of species, intra-specific variability of toxin production or divergence of $C$. tropicalis between the Pacific and Atlantic Oceans.

According to Boente-Juncal et al. [5], 44-methyl gambierone exhibits similar biological activities to gambierone and CTX3, leading to the decreased viability of undifferentiated neuroblastoma cells and modified expression of excitatory neurotransmitter receptor subunits. This compound can be produced by diverse Gambierdiscus species, mainly by G. australes, G. belizeanus and G. polynesiensis, which produce large amounts (reviewed in Longo et al. 2019). Intra-cellular contents of 44-methyl gambierone ranged from 5.8 to 74.1 pg MTX1 eq. cell ${ }^{-1}$ in G. polynesiensis (Longo et al. 2019). In the smaller C. tropicalis cells (G. polynsiensis is twice the size of $C$. tropicalis, see [40] and Table 1 above), we measured 73 and 20 pg MTX1 eq. cell ${ }^{-1}$ of 44-methylgambierone and 44-methylgambierone isomer. Such surprisingly high toxin levels are especially relevant considering that 44-methyl gambierone may be implicated in the neurological manifestations related to ciguatera poisoning (CP) in humans [5]. Thus, the role of C. tropicalis as another causative agent of $\mathrm{CP}$ deserves to be considered in further investigations.

\section{Conclusions}

Coolia is a potentially toxic marine dinoflagellate genus, with many taxonomical and toxicological issues yet to be evaluated and resolved. The smaller-celled Coolia species, including C. malayensis and similar species, cannot be clearly distinguished from each other based only on morphological features. Thus, in studies of any strain from the C. monotis species group (C. monotis, C. malayensis, C. santacroce and C. palmyrensis), the use of molecular data is mandatory. C. malayensis has proved to be the most broadly distributed species of the genus, found in both temperate and tropical waters of the Atlantic and Pacific Oceans, while other species occur in more restricted areas. This study increased from three to five (out of eight) the number of Coolia species reported in Brazilian waters so far, highlighting Brazil as an area of biodiversity for this genus.

Assessment of Coolia toxicity can be rather controversial due to the distinct assays/techniques used, but also due to species-specific differences in the capacity of producing toxic compounds. In the present study, C. malayensis and C. tropicalis cells were toxic to adult Artemia individuals in feeding experiments, while C. santacroce and C. palmyrensis were not. Using both low- and high-resolution LC-MS/MS, we detected considerable amounts of 44-methyl-gambierone (MTX3) — previously limited to Gambierdiscus spp.- -and a new 44-methyl gambierone isomer in C. tropicalis. According to previous studies, this compound exhibits a powerful cytotoxic effect, which might explain the toxicity in bioassays involving this species.

\section{Materials and Methods}

\subsection{Sampling and Cultures}

Toxicity-Nineteen sampling campaigns were conducted from October 2016 to March 2018, at nine sampling sites along the Brazilian Coast (Figure 4), including coastal rocky shores and islands. Samples were collected and processed following the procedures described in Tester et al. [41] Seaweed samples were vigorously shaken to detach particles, and the seawater containing Coolia cells was used for microscopic observation and isolation of living cells. Cells of Coolia were isolated using a 
capillary pipette following successive washing in sterile, local filtered seawater. After initial growth through consecutive cell divisions, the volume of culture was successively doubled by transferring the old aliquot to a larger microplate well, containing an equivalent volume of sterile, $50 \%$ diluted $\mathrm{f} / 2$ media (f/4), without silica and $\sim 32$ salinity. From $10 \mathrm{~mL}$ wells, cultures were transferred to 50 and then $250 \mathrm{~mL}$ Erlenmeyer flasks, where they were maintained at $26{ }^{\circ} \mathrm{C}$ under a $12: 12 \mathrm{~h}$ light cycle (irradiance of $70 \pm 20 \mu \mathrm{mol} \mathrm{m} \mathrm{m}^{-2} \mathrm{~s}^{-1}$ ). Fourteen strains were successfully established and used in the present study (Table 4). For toxin analysis, cultivated cells were harvested at two growth stages (exponential and stationary growth phase). Cells were concentrated by centrifugation ( $2332 \mathrm{~g}, 5 \mathrm{~min})$, the supernatant was removed, and samples were stored at $-20{ }^{\circ} \mathrm{C}$. Prior to toxin analysis, frozen cell pellets were lyophilized.

Table 4. Coolia spp. strains used in the present study.

\begin{tabular}{cccccc}
\hline Specie & Strain & Brazilian state & Latitude (S) & Longitude (W) & Date \\
\hline Coolia malayensis & LM-034 & São Paulo & $23^{\circ} 50^{\prime} 36.90^{\prime \prime}$ & $45^{\circ} 24^{\prime} 15.66^{\prime \prime}$ & $12 / 11 / 2016$ \\
\hline C. malayensis & LM-036 & Rio de Janeiro & $23^{\circ} 03^{\prime} 19.20^{\prime \prime}$ & $44^{\circ} 19^{\prime} 45.42^{\prime \prime}$ & $10 / 11 / 2016$ \\
\hline C. malayensis & LM-058 & Rio de Janeiro & $23^{\circ} 01^{\prime} 16.20^{\prime \prime}$ & $44^{\circ} 19^{\prime} 47.52^{\prime \prime}$ & $23 / 01 / 2017$ \\
\hline C. malayensis & LM-066 & Bahia & $12^{\circ} 34^{\prime} 54.30^{\prime \prime}$ & $38^{\circ} 00^{\prime} 03.90^{\prime \prime}$ & $11 / 03 / 2017$ \\
\hline C. malayensis & LM-085 & Bahia & $12^{\circ} 57^{\prime} 20.46^{\prime \prime}$ & $38^{\circ} 21^{\prime} 36.06^{\prime \prime}$ & $10 / 03 / 2017$ \\
\hline C. malayensis & LM-132 & Alagoas & $09^{\circ} 40^{\prime} 07.52^{\prime \prime}$ & $35^{\circ} 42^{\prime} 45.37^{\prime \prime}$ & $22 / 02 / 2018$ \\
\hline C. malayensis & LM-140 & Rio Grande do Norte & $05^{\circ} 33^{\prime} 53.30^{\prime \prime}$ & $35^{\circ} 04^{\prime} 20.90^{\prime \prime}$ & $10 / 03 / 2018$ \\
\hline Coolia palmyrensis & LM-075 & Pernambuco & $08^{\circ} 35^{\prime} 31.02^{\prime \prime}$ & $34^{\circ} 54^{\prime} 43.02^{\prime \prime}$ & $28 / 03 / 2017$ \\
\hline C. palmyrensis & LM-076 & Pernambuco & $08^{\circ} 35^{\prime} 31.02^{\prime \prime}$ & $34^{\circ} 54^{\prime} 43.02^{\prime \prime}$ & $28 / 03 / 2017$ \\
\hline C. palmyrensis & LM-112 & Bahia (Abrolhos) & $18^{\circ} 02^{\prime} 00.00^{\prime \prime}$ & $38^{\circ} 41^{\prime} 53.88^{\prime \prime}$ & $15 / 10 / 2017$ \\
\hline Coolia santacroce & LM-113 & Bahia (Abrolhos) & $18^{\circ} 02^{\prime} 00.00^{\prime \prime}$ & $38^{\circ} 41^{\prime} 53.88^{\prime \prime}$ & $15 / 10 / 2017$ \\
\hline C. santacroce & LM-122 & Bahia (Abrolhos) & $18^{\circ} 02^{\prime} 00.00^{\prime \prime}$ & $38^{\circ} 41^{\prime} 53.88^{\prime \prime}$ & $15 / 10 / 2017$ \\
\hline C. santacroce & LM-123 & Bahia (Abrolhos) & $18^{\circ} 02^{\prime} 53.88^{\prime \prime}$ & $38^{\circ} 41^{\prime} 53.88^{\prime \prime}$ & $15 / 10 / 2017$ \\
\hline Coolia tropicalis & LM-141 & Rio Grande do Norte & $05^{\circ} 33^{\prime} 53.30^{\prime \prime}$ & $35^{\circ} 04^{\prime} 20.90^{\prime \prime}$ & $11 / 03 / 2018$ \\
\hline
\end{tabular}

\subsection{DNA Amplification, Sequencing and Molecular Phylogeny}

Cultured cells of Coolia spp. were harvested by centrifugation ( $2332 \mathrm{~g}, 5 \mathrm{~min})$. The supernatant was removed and replaced by ethanol to preserve samples until DNA analysis. Before amplification, single cells from ethanol-preserved samples were isolated with a glass capillary and washed six times with deionized water. Single Coolia cells were placed in PCR tubes (at least two tubes for each sample), containing 1-3 $\mu \mathrm{L}$ of deionized water and stored at $-20{ }^{\circ} \mathrm{C}$ before direct PCR amplifications.

Two consecutive PCR reactions (nested PCR) were performed to amplify the rDNA regions ITS1-5.8S-ITS2 (ITS) and LSU (D1-D3). For the first PCR reaction, $2.5 \mu \mathrm{L}$ of each primer (ITSfw and D3B, Table 5), $12.5 \mu$ L of PCR Master Mix 2X (Promega, Madison ${ }^{\circledR}$, WI, USA) containing the Taq DNA polymerase, dNTPs, $\mathrm{MgCl} 2$ and reaction buffers, and $6.5 \mu \mathrm{L}$ of nuclease-free water were added to each tube. The PCR were performed in a Biometra TOne thermocycler (Analytik Jena), as follows: one initial denaturation step at $95{ }^{\circ} \mathrm{C}$ for $2 \mathrm{~min}$, then 35 cycles of $30 \mathrm{~s}$ at $95{ }^{\circ} \mathrm{C}, 1 \mathrm{~min}$ at $62{ }^{\circ} \mathrm{C}$ (melting temperature, "MT") and $1 \mathrm{~min}$ at $72{ }^{\circ} \mathrm{C}$, and a final elongation step of $5 \mathrm{~min} 72{ }^{\circ} \mathrm{C}$. For the second PCR reaction, $1 \mu \mathrm{L}$ of the first product was added to a new tube containing $2.5 \mu \mathrm{L}$ of each primer (ITSfw and 28S364r for ITS region; D1R and D3B for D1-D3; Table 3), $12.5 \mu \mathrm{L}$ of GoTaq ${ }^{\circledR}$ G2 Hot Start Green Master Mix (Promega ${ }^{\circledR}$, Madison, WI, USA) and $6.5 \mu \mathrm{L}$ of nuclease-free water. The second PCR was performed as the first one, changing the MT to $50{ }^{\circ} \mathrm{C}$ for ITS, and $56^{\circ} \mathrm{C}$ for D1-D3 region. DNA amplifications were controlled by electrophoresis on agarose gel. Positive samples were purified and sequenced, as described in Chomérat et al. [42] 
The alignment and phylogenetic analyses were performed as described in Chomérat et al. [42], with modifications as described below. Both ITS and D1-D3 rDNA region datasets were aligned using MAFFT algorithm, with selection of the q-ins-i strategy [43]. Poorly aligned positions were removed using Gblocks algorithm [44], and the most appropriate model of sequence evolution was selected using jModeltest2 v. 2.1.10 [45]. For both rDNA regions, $\mathrm{TrN}+\mathrm{G}$ were the models used for Maximum Likelihood (ML) and Bayesian Inference (BI) analysis, with 2,000,000 generations performed in BI analysis for both alignments, and sampling every 100 generations. The posterior probabilities of each clade were calculated from the remaining 20,000 trees. For some samples, the primer Coo5.8f (Table 5) was used in the sequencing reaction to obtain clearer sequences from ITS2.

Table 5. Oligonucleotide primers used in the present study.

\begin{tabular}{ccc}
\hline Primer & Sequence & Reference \\
\hline ITSfw & 5'-GTAGGTGAACCTGCGGAAGG-3' $^{\prime}$ & {$[46]$} \\
\hline Coo5.8f & 5'-ATGCAGAATCCCGTGAATCA-3' $^{\prime}$ & Present study \\
\hline D1R & 5'-ACCCGCTGAATTTAAGCATA-3' $^{\prime}$ & {$[47]$} \\
\hline 364R & 5'-CTCTCTTTTCAAAGTCCTTTTC-3' $^{\prime}$ & Present study \\
\hline D3B & 5'-TCGGAGGGAACCAGCTACTA-3' $^{\prime}$ & {$[48]$} \\
\hline
\end{tabular}

\subsection{Morphological Observations}

Prior to the scanning electron microscopy (SEM) observations, cultured Coolia cells were preserved with neutral and acidic lugol (1\%). Small sample aliquots $(2-5 \mathrm{~mL})$ were placed on a piece of either a $5 \mu \mathrm{m}$ Millipore filter or a $20 \mu \mathrm{m}$ plankton net, rinsed with distilled water, and dehydrated in a series of increasing ethanol concentrations (30\%,50\%,70\%, 90\%, 95\% and 100\%), followed by critical point drying. Samples were finally mounted on a stub and sputter coated with gold palladium. Cells were observed using a JEOL ${ }^{\circledR}$ JSM 6360-LV (Japan) microscope at 15 Kv. Species identification was based mainly on original and recent Coolia spp. descriptions [11,15,16,18].

\subsection{Toxicity Experiments}

The toxicity of selected Coolia spp. strains was evaluated through bioassays using adult individuals of the brine shrimp Artemia salina. After cyst hatching, A. salina larvae were kept in controlled tanks under constant aeration and fed non-toxic Tetraselmis suecica cells for 20-30 days. Then, adult specimens of $A$. salina were individually placed in wells of cell culture plates containing $5 \mathrm{~mL}$ of autoclaved sea water each. Before each test, plates containing $A$. salina were acclimated for $24-48 \mathrm{~h}$ under the experimental conditions and fed with T. suecica in an amount equivalent to $150 \mathrm{ng} C \mathrm{ind}^{-1} \mathrm{~h}^{-1}$. During the test, they were exposed to increasing cell densities (i.e., treatments) of Coolia spp. and a complementary amount of non-toxic T. suecica cells, in order to maintain a comparable food supply over all treatments. Cell density of each strain depended on their cell biovolumes, which were calculated from approximate geometrical shapes after measuring 50 cells of each strain [49]. Cell biovolume was then converted into carbon biomass, following conversion factors described in Menden-Deuer et al. [50] The in vivo toxicity assays aimed at providing quantities of Coolia spp. equivalent to 4.7, 9.4, 18.8, 37.5, 75 and $150 \mathrm{ng} \mathrm{C}$ ind ${ }^{-1} \mathrm{~h}^{-1}$ for $96 \mathrm{~h}$. The maximum biomass possible (according to each culture cell densities at late exponential growth phase), as well as half of the maximum, were also used as additional treatments. Maximum Coolia spp. quantities tested were equivalent to 965, 800, 750, 575 ng $\mathrm{C}$ ind $^{-1} \mathrm{~h}^{-1}$ for C. malayensis, C. tropicalis, C. santacroce, and C. palmyrensis, respectively.

Three cell culture plates were used for each experimental treatment, each containing twelve individuals of $A$. salina. From those, ten individuals were exposed to the toxic microalgae and the other two were exposed to the control condition, consisting of non-toxic T. suecica cells only. An extra plate containing twelve brine shrimps was used to increase the number of control individuals to 60, while 
30 individuals were exposed to each treatment containing Coolia cells, adding up to 300 brine shrimps in each experiment. Survival of $A$. salina was evaluated after 1, 3, 12, 24, 48, 72 and 96 h of exposure. Individuals were considered dead if completely motionless at the bottom for 10 consecutive seconds.

\subsection{Toxin Analysis}

Prior to toxin analysis, cell pellets were sonicated in bath ultrasound (Transonic TI-H-15, Elma ${ }^{\circledR}$, Germany) at $45 \mathrm{kHz}$ for $15 \mathrm{~min}$ with methanol/water (9:1, v/v). The mixture was centrifuged at $1200 \mathrm{~g}$ for $15 \mathrm{~min}$. Supernatant was passed through a centrifuge NanoSep filter $\left(0.2 \mu \mathrm{m}\right.$ Nylon, PALL ${ }^{\circledR}$, UK) and recovered into plastic vials with conical insert.

Filtered extracts from cell pellets were analyzed using two hybrid systems coupling ultra-high-performance liquid chromatography with tandem mass spectrometry (UHPLC-MS/MS), in either low- (LR) or high-resolution (HR).

\subsubsection{System A: HR-MS/MS}

System A was composed of a UHPLC system (1290 Infinity II, Agilent Technologies, Santa Clara, CA, USA) coupled to a 6550 ifunnel Q-TOF (Agilent Technologies, CA, USA), equipped with a Dual Jet Stream ${ }^{\circledR}$ ESI source. The high-resolution instrument was operated in both full scan and targeted MS/MS modes. Acquisition was carried out in positive and negative ionization modes, with optimized parameter sources. Temperature was set at $250{ }^{\circ} \mathrm{C}$, drying gas flow at $16 \mathrm{~L} \mathrm{~min}^{-1}$, nebulizer gas at 15 psi and sheath gas at $12 \mathrm{~L} \mathrm{~min}^{-1}$ and $400{ }^{\circ} \mathrm{C}$. Capillary and nozzle voltages were set at $5000 \mathrm{~V}$ and $1000 \mathrm{~V}$, respectively. Two reference masses $m / z 121.0509$ (purine) and $m / z 922.0099$ (hexakis phosphazine) were continuously monitored during the run.

The chromatographic conditions were similar to those described for system B in Section 5.5.2 below, except for the porosity of the Kinetex C18 column used (1.7 $\mu \mathrm{m}$, instead of $2.6 \mu \mathrm{m})$. Mass spectra

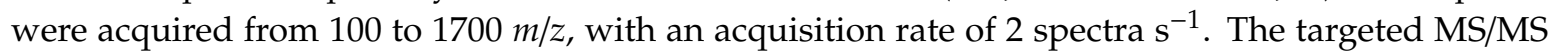

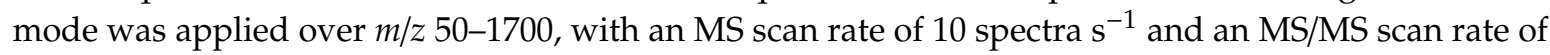

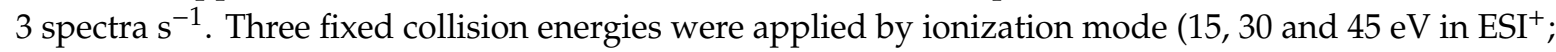
30, 45 and $90 \mathrm{eV}$ in $\mathrm{ESI}^{-}$), to obtain an overview of the fragmentation pathways. Instrument control, data processing and analysis were conducted using Mass Hunter software v.8.0 (Agilent Technologies, CA, USA).

\subsubsection{System B: LR-MS/MS}

System B was composed of a UHPLC system (UFLC Nexera, SHIMADZU, Japan), coupled to a hybrid triple quadrupole-linear ion-trap API4000 Qtrap mass spectrometer (ABSciex ${ }^{\circledR}$, Framingham, MA, USA), equipped with a TurboV ${ }^{\circledR}$ electrospray ionization source (ESI). The instrument control, data processing and analysis were conducted using Analyst software 1.6.2 (SCIEX, CA, USA).

A linear gradient using water as eluent $\mathrm{A}$ and $95 \%$ acetonitrile as eluent $\mathrm{B}$, both eluents containing $2 \mathrm{mM}$ ammonium formate and $50 \mathrm{mM}$ formic acid, was run through a Kinetex C18 column, $50 \times 2.1 \mathrm{~mm}$, $2.6 \mu \mathrm{m}, 100 \AA$ (Phenomenex, Torrance, CA, USA). The flow rate was $0.4 \mathrm{~mL} \mathrm{~min}^{-1}$, the injection volume was $5 \mu \mathrm{L}$ and the column temperature was $40{ }^{\circ} \mathrm{C}$. The elution gradient was set as follows: $10 \% \mathrm{~B}$ to $95 \%$ B from 0 to $10 \mathrm{~min}$, hold at $95 \%$ B for $2 \mathrm{~min}$, decrease from $95 \%$ to $10 \%$ in $1 \mathrm{~min}$ and hold during 3 min to equilibrate. Mass spectrometric detection was performed in negative ionization mode using MRM scanning. The $m / z$ transition used is listed in Table 6 for Gambierdiscus metabolites and in Table S2 for YTXs toxins, for which certified standards were available. The optimized ESI- parameters were set as follows: curtain gas at 25 psi, ion spray at $-4500 \mathrm{~V}$, turbo gas temperature at $500{ }^{\circ} \mathrm{C}$, gas 1 and 2 at 50 psi, declustering potential at $-210 \mathrm{~V}$ for Gambierdiscus metabolites and $-120 \mathrm{~V}$ for YTXs toxins and an entrance potential at $-10 \mathrm{~V}$. 
Table 6. List of MRM transitions $(\mathrm{m} / \mathrm{z})$ used in ESI- to detect MTXs, gambierone toxins and gambieric acids on system B (API 4000QTrap).

\begin{tabular}{|c|c|c|c|c|}
\hline Compound & \multicolumn{2}{|c|}{ MRM transitions $(m / z)$} & $\mathrm{CE}(\mathrm{eV})$ & CXP (eV) \\
\hline \multirow{4}{*}{ MTX1 } & $1689.8>1689.6$ & {$[\mathrm{M}-2 \mathrm{H}]^{2-} /[\mathrm{M}-2 \mathrm{H}]^{2-}$} & -40 & -15 \\
\hline & $1689.8>96.9$ & {$[\mathrm{M}-2 \mathrm{H}]^{2-} /\left[\mathrm{HOSO}_{3}\right]^{2-}$} & -125 & -21 \\
\hline & $1126.2>1126.2$ & {$[\mathrm{M}-3 \mathrm{H}]^{3-} /[\mathrm{M}-3 \mathrm{H}]^{3-}$} & -40 & -15 \\
\hline & $1126.2>96.9$ & {$[\mathrm{M}-3 \mathrm{H}]^{3-} /\left[\mathrm{HOSO}_{3}\right]^{3-}$} & -125 & -21 \\
\hline \multirow{4}{*}{ MTX2 } & $1637.5>1637.5$ & {$[\mathrm{M}-2 \mathrm{H}]^{2-} /[\mathrm{M}-2 \mathrm{H}]^{2-}$} & -40 & -15 \\
\hline & $1637.5>96.9$ & {$[\mathrm{M}-2 \mathrm{H}]^{2-} /\left[\mathrm{HOSO}_{3}\right]^{2-}$} & -125 & -21 \\
\hline & $1091.5>1091.5$ & {$[\mathrm{M}-3 \mathrm{H}]^{3-} /[\mathrm{M}-3 \mathrm{H}]^{3-}$} & -40 & -15 \\
\hline & $1091.5>96.9$ & {$[\mathrm{M}-3 \mathrm{H}]^{3-} /\left[\mathrm{HOSO}_{3}\right]^{3-}$} & -125 & -21 \\
\hline \multirow{2}{*}{ MTX4 } & $1646.2>1646.2$ & {$[\mathrm{M}-2 \mathrm{H}]^{2-} /[\mathrm{M}-2 \mathrm{H}]^{2-}$} & -40 & -15 \\
\hline & $1646.2>96.9$ & {$[\mathrm{M}-2 \mathrm{H}]^{2-} /\left[\mathrm{HOSO}_{3}\right]^{2-}$} & -125 & -21 \\
\hline \multirow{2}{*}{ desulfo-MTX1 } & $1649.8>1649.8$ & {$[\mathrm{M}-2 \mathrm{H}]^{2-} /[\mathrm{M}-2 \mathrm{H}]^{2-}$} & -40 & -15 \\
\hline & $1649.8>96.9$ & {$[\mathrm{M}-2 \mathrm{H}]^{2-} /\left[\mathrm{HOSO}_{3}\right]^{2-}$} & -125 & -21 \\
\hline \multirow{2}{*}{$\begin{array}{c}\text { didehydro-demethyl- } \\
\text { desulfo-MTX1 }\end{array}$} & $1641.8>1641.8$ & {$[\mathrm{M}-2 \mathrm{H}]^{2-} /[\mathrm{M}-2 \mathrm{H}]^{2-}$} & -40 & -15 \\
\hline & $1641.8>96.9$ & {$[\mathrm{M}-2 \mathrm{H}]^{2-} /\left[\mathrm{HOSO}_{3}\right]^{2-}$} & -125 & -21 \\
\hline \multirow{2}{*}{ Gambierone } & $1023.5>1023.5$ & {$[\mathrm{M}-\mathrm{H}]^{-} /[\mathrm{M}-\mathrm{H}]^{-}$} & -40 & -15 \\
\hline & $1023.5>96.9$ & {$[\mathrm{M}-\mathrm{H}]^{-} /\left[\mathrm{HOSO}_{3}\right]^{-}$} & -125 & -21 \\
\hline \multirow{2}{*}{ 44-methylgambierone } & $1037.6>1037.6$ & {$[\mathrm{M}-\mathrm{H}]^{-} /[\mathrm{M}-\mathrm{H}]^{-}$} & -40 & -15 \\
\hline & $1037.6>96.9$ & {$[\mathrm{M}-\mathrm{H}]^{-} /\left[\mathrm{HOSO}_{3}\right]^{-}$} & -125 & -21 \\
\hline \multirow{2}{*}{ Gambieroxide } & $1193.6>1193.6$ & {$[\mathrm{M}-\mathrm{H}]^{-} /[\mathrm{M}-\mathrm{H}]^{-}$} & -20 & -15 \\
\hline & $1193.6>96.9$ & {$[\mathrm{M}-\mathrm{H}]^{-} /\left[\mathrm{HOSO}_{3}\right]^{-}$} & -125 & -21 \\
\hline \multirow{2}{*}{ Gambieric acid A } & 1055.1 > 1055.1 & {$[\mathrm{M}-\mathrm{H}]^{-} /[\mathrm{M}-\mathrm{H}]^{-}$} & -20 & -15 \\
\hline & 1055.1 > 1037.1 & {$[\mathrm{M}-\mathrm{H}]^{-} /\left[\mathrm{M}-\mathrm{H}-\mathrm{H}_{2} \mathrm{O}\right]^{-}$} & -40 & -15 \\
\hline \multirow{2}{*}{ Gambieric acid B } & 1069.1 > 1069.1 & {$[\mathrm{M}-\mathrm{H}]^{-} /[\mathrm{M}-\mathrm{H}]^{-}$} & -20 & -15 \\
\hline & 1069.1 > 1051.1 & {$[\mathrm{M}-\mathrm{H}]^{-} /\left[\mathrm{M}-\mathrm{H}-\mathrm{H}_{2} \mathrm{O}\right]^{-}$} & -40 & -15 \\
\hline \multirow{2}{*}{ Gambieric acid C } & $1183.7>1183.7$ & {$[\mathrm{M}-\mathrm{H}]^{-} /[\mathrm{M}-\mathrm{H}]^{-}$} & -20 & -15 \\
\hline & $1183.7>1165.7$ & {$[\mathrm{M}-\mathrm{H}]^{-} /\left[\mathrm{M}-\mathrm{H}-\mathrm{H}_{2} \mathrm{O}\right]^{-}$} & -40 & -15 \\
\hline \multirow{2}{*}{ Gambieric acid D } & $1197.7>1197.7$ & {$[\mathrm{M}-\mathrm{H}]^{-} /[\mathrm{M}-\mathrm{H}]^{-}$} & -20 & -15 \\
\hline & $1197.7>1179.7$ & {$[\mathrm{M}-\mathrm{H}]^{-} /\left[\mathrm{M}-\mathrm{H}-\mathrm{H}_{2} \mathrm{O}\right]^{-}$} & -40 & -15 \\
\hline
\end{tabular}

\subsubsection{Quantification of Gambierone Toxins in C. tropicalis}

In order to quantify the MTX and gambierone toxins, a calibration curve of MTX1 was prepared from successive dilutions of a standard solution (Wako, Japan) in $50 \% \mathrm{MeOH}$, with concentrations ranging from 0.2 to $5.0 \mu \mathrm{g} \mathrm{mL} \mathrm{m}^{-1}$. Due to the lack of analytical standards, each targeted compound was quantified from the MTX1 calibration curve prepared, assuming equivalent molar response. The amounts of gambierone toxins present in the C. tropicalis extract were estimated using the MRM transition $[\mathrm{M}-\mathrm{H}]^{-} /[\mathrm{M}-\mathrm{H}]^{-}$, whereas the bi-charged molecular anion $[\mathrm{M}-2 \mathrm{H}]^{2-} /[\mathrm{M}-2 \mathrm{H}]^{2-}$ was used for MTX1. This was necessary, since the singly charged ion of MTX-1 is out of the mass range effectively detected by the instrument $(50-2800 \mathrm{Da})$.

Supplementary Materials: The following are available online at http://www.mdpi.com/2072-6651/12/5/327/s1, Table S1. List of compounds extracted from the Personal Compound Database and Library (PCDL, Agilent Mass Hunter software), created by Phycotoxins Laboratory (IFREMER, France) and used for Coolia spp. Screening, Table S2: List of MRM transitions $(\mathrm{m} / \mathrm{z}$ ) used in ESI- to detect YTXs on system B (API 4000QTrap), Figure S1. (A) LC-HRMS chromatogram of C. tropicalis extract and high resolution full scan mass spectra acquired in negative mode on the apex of peaks at (A1) $6.0 \mathrm{~min}$ for 44-methyl gambierone isomer and (A2) at $6.6 \mathrm{~min}$ for 44-methyl gambierone, Figure S2. HRMS/MS spectra of [M-H]- $(\mathrm{m} / \mathrm{z}$ 1037.4785) for (A) 44-methyl gambierone isomer at $6.0 \mathrm{~min}$ and for (B) 44-methyl gambierone at $6.6 \mathrm{~min}$, resulting from an average of three collision energies $(40,65$ and $90 \mathrm{eV}$ ).

Author Contributions: Conceptualization, C.E.J.d.A.T., P.H. and L.L.M.J.; Data curation, C.E.J.d.A.T.; Formal analysis, C.E.J.A.T., L.F.F., G.B., M.S. and L.L.M.J.; Funding acquisition, P.H. and L.L.M.J.; Resources, N.C. and P.H.; Supervision, L.F.F., N.C., P.H. and L.L.M.J.; Writing—original draft, C.E.J.A.T.; Writing—review \& editing, L.F.F., N.C., M.S., P.H. and L.L.M.J. All authors have read and agreed to the published version of the manuscript. 
Funding: This research was funded by International Atomic Energy Agency (IAEA) through the Bentox Project, RC\# 18827, and the IAEA Core Research Project K41014. Further funding was obtained from Coordenação de Aperfeiçoamento de Pessoal de Nível Superior (CAPES): PVEX, n. 88881.172853/2018-01; and PDSE, n. 88881.190128/2018-01. P.H. and N.C. acknowledge the European H2020 program for funding the EMERTOX project (grant number 778069). The APC was funded by H2020 778069-EMERTOX.

Conflicts of Interest: The authors declare no conflicts of interest.

\section{References}

1. Hoppenrath, M.; Murray, S.A.; Chomérat, N.; Horiguchi, T. Marine Benthic Dinoflagellates—Unveiling Their Worldwide Biodiversity; Senckenberg-Reihe: Frankfurt, Germany, 2014; ISBN 978-3-510-61402-8.

2. Parsons, M.L.; Aligizaki, K.; Bottein, M.Y.D.; Fraga, S.; Morton, S.L.; Penna, A.; Rhodes, L. Gambierdiscus and Ostreopsis: Reassessment of the state of knowledge of their taxonomy, geography, ecophysiology, and toxicology. Harmful Algae 2012, 14, 107-129. [CrossRef]

3. Yogi, K.; Oshiro, N.; Inafuku, Y.; Hirama, M.; Yasumoto, T. Detailed LC-MS/MS Analysis of Ciguatoxins Revealing Distinct Regional and Species Characteristics in Fish and Causative Alga from the Pacific. Anal. Chem. 2011, 83, 8886-8891. [CrossRef] [PubMed]

4. Friedman, M.A.; Fernandez, M.; Backer, L.C.; Dickey, R.W.; Bernstein, J.; Schrank, K.; Kibler, S.; Stephan, W.; Gribble, M.O.; Bienfang, P.; et al. An updated review of ciguatera fish poisoning: Clinical, epidemiological, environmental, and public health management. Mar. Drugs 2017, 15, 72. [CrossRef]

5. Boente-Juncal, A.; Álvarez, M.; Antelo, Á.; Rodríguez, I.; Calabro, K.; Vale, C.; Thomas, O.P.; Botana, L.M. Structure elucidation and biological evaluation of maitotoxin-3, a homologue of gambierone, from Gambierdiscus belizeanus. Toxins 2019, 11, 79. [CrossRef]

6. Nagai, H.; Torigoe, K.; Satake, M.; Murata, M.; Yasumoto, T.; Hirota, H. Gambieric Acids: Unprecedented Potent Antifungal Substances Isolated from Cultures of a Marine Dinoflagellate Gambierdiscus toxicus. J. Am. Chem. Soc. 1992, 114, 1102-1103. [CrossRef]

7. Cagide, E.; Louzao, M.C.; Espiña, B.; Ares, I.R.; Vieytes, M.R.; Sasaki, M.; Fuwa, H.; Tsukano, C.; Konno, Y.; Yotsu-Yamashita, M.; et al. Comparative cytotoxicity of gambierol versus other marine neurotoxins. Chem. Res. Toxicol. 2011, 24, 835-842. [CrossRef]

8. Watanabe, R.; Uchida, H.; Suzuki, T.; Matsushima, R.; Nagae, M.; Toyohara, Y.; Satake, M.; Oshima, Y.; Inoue, A.; Yasumoto, T. Gambieroxide, a novel epoxy polyether compound from the dinoflagellate Gambierdiscus toxicus GTP2 strain. Tetrahedron 2013, 69, 10299-10303. [CrossRef]

9. Longo, S.; Sibat, M.; Viallon, J.; Darius, H.T.; Hess, P.; Chinain, M. Intraspecific variability in the toxin production and toxin profiles of in vitro cultures of Gambierdiscus polynesiensis (Dinophyceae) from French polynesia. Toxins 2019, 11, 1-23. [CrossRef] [PubMed]

10. Hoppenrath, M.; Chomérat, N.; Horiguchi, T.; Schweikert, M.; Nagahama, Y.; Murray, S. Taxonomy and phylogeny of the benthic Prorocentrum species (Dinophyceae)—A proposal and review. Harmful Algae 2013, 27, 1-28. [CrossRef]

11. Karafas, S.; Teng, S.T.; Leaw, C.P.; Alves-de-Souza, C. An evaluation of the genus Amphidinium (Dinophyceae) combining evidence from morphology, phylogenetics, and toxin production, with the introduction of six novel species. Harmful Algae 2017, 68, 128-151. [CrossRef]

12. Moreira-González, A.R.; Fernandes, L.F.; Uchida, H.; Uesugi, A.; Suzuki, T.; Chomérat, N.; Bilien, G.; Pereira, T.A.; Mafra, L.L. Morphology, growth, toxin production, and toxicity of cultured marine benthic dinoflagellates from Brazil and Cuba. J. Appl. Phycol. 2019, 31, 3699-3719. [CrossRef]

13. Lassus, P.; Chomérat, N.; Hess, P.; Nézan, E. Toxic and Harmful Microalgae of the World Ocean; Intergovernmental Oceanographic Commission of UNESCO: Copenhagen, Denmark, 2016; ISBN 978-87-990827-6-6.

14. Leaw, C.P.; Tan, T.H.; Lim, H.C.; Teng, S.T.; Yong, H.L.; Smith, K.F.; Rhodes, L.; Wolf, M.; Holland, W.C.; Vandersea, M.W.; et al. New scenario for speciation in the benthic dinoflagellate genus Coolia (Dinophyceae). Harmful Algae 2016, 55, 137-149. [CrossRef] [PubMed]

15. David, H.; Laza-Martínez, A.; Rodríguez, F.; Fraga, S.; Orive, E. Coolia guanchica sp. nov. (Dinophyceae) a new epibenthic dinoflagellate from the Canary Islands (NE Atlantic Ocean). Eur. J. Phycol. 2020, 55, 76-88. [CrossRef]

16. Faust, M.A. Observation of sand-dwelling toxic dinoflagellates (Dinophyceae) from widely differing sites, including two new species. J. Phycol. 1995, 31, 996-1003. [CrossRef] 
17. Mohammad-Noor, N.; Moestrup, Ø.; Lundholm, N.; Fraga, S.; Adam, A.; Holmes, M.J.; Saleh, E. Autecology and phylogeny of Coolia tropicalis and Coolia malayensis (Dinophyceae), with emphasis on taxonomy of C. tropicalis based on light microscopy, scanning electron microscopy and LSU rDNA1. J. Phycol. 2013, 49, 536-545. [CrossRef] [PubMed]

18. Leaw, C.P.; Lim, P.T.; Cheng, K.W.; Ng, B.K.; Usup, G. Morphology and molecular characterization of a new species of thecate benthic dinoflagellate, Coolia malayensis sp. nov. (Dinophyceae). J. Phycol. 2010, 46, 162-171. [CrossRef]

19. Karafas, S.; York, R.; Tomas, C. Morphological and genetic analysis of the Coolia monotis species complex with the introduction of two new species, Coolia santacroce sp. nov. and Coolia palmyrensis sp. nov. (Dinophyceae). Harmful Algae 2015, 46, 18-33. [CrossRef]

20. Karafas, S.J.; Tomas, C.R. Further observations on the genetics and morphometrics of Coolia santacroce (Dinophyceae). Algae 2015, 30, 275-280. [CrossRef]

21. Durán-Riveroll, L.M.; Cembella, A.D.; Okolodkov, Y.B. A review on the biodiversity and biogeography of toxigenic benthic marine dinoflagellates of the coasts of Latin America. Front. Mar. Sci. 2019, 6, 1-25. [CrossRef]

22. Larsson, M.E.; Smith, K.F.; Doblin, M.A. First description of the environmental niche of the epibenthic dinoflagellate species Coolia palmyrensis, C. malayensis, and C. tropicalis (Dinophyceae) from Eastern Australia. J. Phycol. 2019, 55, 565-577. [CrossRef]

23. Fraga, S.; Penna, A.; Bianconi, I.; Paz, B.; Zapata, M. Coolia canariensis sp. nov. (Dinophyceae), a new nontoxic epiphytic benthic dinoflagellate from the Canary Islands. J. Phycol. 2008, 44, 1060-1070. [CrossRef] [PubMed]

24. David, H.; Laza-Martínez, A.; Miguel, I.; Orive, E. Broad distribution of Coolia monotis and restricted distribution of Coolia cf. canariensis (Dinophyceae) on the Atlantic coast of the Iberian Peninsula. Phycologia 2014, 53, 342-352. [CrossRef]

25. Ten-Hage, L.; Turquet, J.; Quod, J.P.; Coute, A. Coolia areolata sp. nov. (Dinophyceae), a new sand-dwelling dinoflagellate from the southwestern Indian Ocean. Phycologia 2009, 39, 377-383. [CrossRef]

26. Gómez, F.; Qiu, D.; Otero-Morales, E.; Lopes, R.M.; Lin, S. Circumtropical distribution of the epiphytic dinoflagellate Coolia malayensis (Dinophyceae): Morphology and molecular phylogeny from Puerto Rico and Brazil. Phycol. Res. 2016, 64, 194-199. [CrossRef]

27. De Queiro sMendes, M.C.; De Castro Nunes, J.M.; Fraga, S.; Rodríguez, F.; Franco, J.M.; Riobó, P.; Branco, S.; Menezes, M. Morphology, molecular phylogeny and toxinology of Coolia and Prorocentrum strains isolated from the tropical South Western Atlantic Ocean. Bot. Mar. 2019, 62, 125-140. [CrossRef]

28. Nascimento, S.M.; da Silva, R.A.F.; Oliveira, F.; Fraga, S.; Salgueiro, F. Morphology and molecular phylogeny of Coolia tropicalis, Coolia malayensis and a new lineage of the Coolia canariensis species complex (Dinophyceae) isolated from Brazil. Eur. J. Phycol. 2019, 54, 1-13. [CrossRef]

29. Nakajima, I.; Oshima, Y.; Yasumoto, T. Toxicity of Benthic Dinoflagellates in Okinawa. Nippon Suisan Gakkaishi 1981, 47, 1029-1033. [CrossRef]

30. Holmes, M.J.; Lewis, R.J.; Jones, A.; Hoy, A.W.W. Cooliatoxin, the first toxin from Coolia monotis (dinophyceae). Nat. Toxins 1995, 3, 355-362. [CrossRef]

31. Rhodes, L.; Adamson, J.; Suzuki, T.; Briggs, L.; Garthwaite, I. Toxic marine epiphytic dinoflagellates, Ostreopsis siamensis and Coolia monotis (Dinophyceae), in New Zealand. N. Z. J. Mar. Freshw. Res. 2000, 34, 371-383. [CrossRef]

32. Wakeman, K.C.; Yamaguchi, A.; Roy, M.C.; Jenke-Kodama, H. Morphology, phylogeny and novel chemical compounds from Coolia malayensis (Dinophyceae) from Okinawa, Japan. Harmful Algae 2015, 44, 8-19. [CrossRef]

33. Penna, A.; Vila, M.; Fraga, S.; Giacobbe, M.G.; Francesco, A.; Riobó, P.; Vernesi, C. Characterization of Ostreopsis and Coolia (Dinophyceae) isolates in the western Mediterranean Sea based on morphology, toxicity and internal transcribed spacer 5.8s rDNA sequences. J. Phycol. 2005, 41, 212-225. [CrossRef]

34. Laza-Martinez, A.; Orive, E.; Miguel, I. Morphological and genetic characterization of benthic dinoflagellates of the genera Coolia, Ostreopsis and Prorocentrum from the south-eastern Bay of Biscay. Eur. J. Phycol. 2011, 46, 45-65. [CrossRef]

35. Murray, J.S.; Selwood, A.I.; Harwood, D.T.; van Ginkel, R.; Puddick, J.; Rhodes, L.L.; Rise, F.; Wilkins, A.L. 44-Methylgambierone, a new gambierone analogue isolated from Gambierdiscus australes. Tetrahedron Lett. 2019, 60, 621-625. [CrossRef] 
36. Estevez, P.; Sibat, M.; Leao, J.M.; Tudó, A.; Rambla-Alegre, M.; Aligizak, K.; Gago-Martinez, A.; Diogène, J.; Hess, P. Use of Mass Spectrometry to determine the Diversity of Toxins Produced by Gambierdiscus and Fukuyoa Species from Balearic Islands and Crete (Mediterranean Sea) and the Canary Islands (Northeast Atlantic). Toxins 2020, 12, 305. [CrossRef] [PubMed]

37. Ho, T.V.; Nguyen, L.N. Morphology and Distribution of the Three Epiphytic Dinoflagellate species Coolia monotis, C. tropicalis, and C. canariensis (Ostreopsidaceae, Gonyaulacales, Dinophyceae) from Vietnamese Coastal Waters. Ocean Sci. J. 2014, 49, 211-221. [CrossRef]

38. Jeong, H.J.; Yih, W.; Kang, N.S.; Lee, S.Y.; Yoon, E.Y.; Yoo, Y. Du; Kim, H.S.; Kim, J.H. First report of the epiphytic benthic dinoflagellates Coolia canariensis and Coolia malayensis in the waters off Jeju Island, Korea: Morphology and rDNA sequences. J. Eukaryot. Microbiol. 2012, 59, 114-133. [CrossRef]

39. Rhodes, L.L.; Smith, K.F.; Munday, R.; Selwood, A.I.; McNabb, P.S.; Holland, P.T.; Bottein, M.Y. Toxic dinoflagellates (Dinophyceae) from Rarotonga, Cook Islands. Toxicon 2010, 56, 751-758. [CrossRef]

40. Litaker, R.W.; Vandersea, M.W.; Faust, M. a.; Kibler, S.R.; Chinain, M.; Holmes, M.J.; Holland, W.C.; Tester, P. a. Taxonomy of Gambierdiscus including four new species, Gambierdiscus caribaeus, Gambierdiscus carolinianus, Gambierdiscus carpenteri and Gambierdiscus ruetzleri (Gonyaulacales, Dinophyceae). Phycologia 2009, 48, 344-390. [CrossRef]

41. Tester, P.A.; Kibler, S.R.; Holland, W.C.; Usup, G.; Vandersea, M.W.; Leaw, C.P.; Teen, L.P.; Larsen, J.; Mohammad-Noor, N.; Faust, M.A.; et al. Sampling harmful benthic dinoflagellates: Comparison of artificial and natural substrate methods. Harmful Algae 2014, 39, 8-25. [CrossRef]

42. Chomérat, N.; Bilien, G.; Derrien, A.; Henry, K.; Ung, A.; Viallon, J.; Darius, H.T.; Mahana iti Gatti, C.; Roué, M.; Hervé, F.; et al. Ostreopsis lenticularis Y. Fukuyo (Dinophyceae, Gonyaulacales) from French Polynesia (South Pacific Ocean): A revisit of its morphology, molecular phylogeny and toxicity. Harmful Algae 2019, 84, 95-111.

43. Katoh, K.; Standley, D.M. MAFFT multiple sequence alignment software version 7: Improvements in performance and usability. Mol. Biol. Evol. 2013, 30, 772-780. [CrossRef] [PubMed]

44. Castresana, J. Selection of conserved blocks from multiple alignments for their use in phylogenetic analysis. Mol. Biol. Evol. 2000, 17, 540-552. [CrossRef] [PubMed]

45. Darriba, D.; Taboada, G.L.; Doallo, R.; Posada, D. JModelTest 2: More models, new heuristics and parallel computing. Nat. Methods 2012, 9, 772. [CrossRef] [PubMed]

46. Adam, R.D.; Ortega, Y.R.; Gilman, R.H.; Sterling, C.R. Intervening transcribed spacer region 1 variability in Cyclospora cayetanensis. J. Clin. Microbiol. 2000, 38, 2339-2343. [CrossRef] [PubMed]

47. Scholin, C.A.; Herzog, M.; Sogin, M.; Anderson, D.M. Identification of group- and strain-specific genetic markers for globally distributed Alexandrium (Dinophyceae). II. Sequence analysis of a fragment of the LSU rRNA gene1. J. Phycol. 1994, 30, 999-1011. [CrossRef]

48. Nunn, G.B.; Theisen, B.F.; Christensen, B.; Arctander, P. Simplicity-correlated size growth of the nuclear $28 \mathrm{~S}$ ribosomal RNA D3 expansion segment in the crustacean order Isopoda. J. Mol. Evol. 1996, 42, 211-223. [CrossRef]

49. Hillebrand, H.; Dürselen, C.D.; Kirschtel, D.; Pollingher, U.; Zohary, T. Biovolume calculation for pelagic and benthic microalgae. J. Phycol. 1999, 35, 403-424. [CrossRef]

50. Menden-Deuer, S.; Lessard, E.J. Carbon to volume relationships for dinoflagellates, diatoms, and other protist plankton. Limnol. Oceanogr. 2000, 45, 569-579. [CrossRef]

(C) 2020 by the authors. Licensee MDPI, Basel, Switzerland. This article is an open access article distributed under the terms and conditions of the Creative Commons Attribution (CC BY) license (http://creativecommons.org/licenses/by/4.0/). 